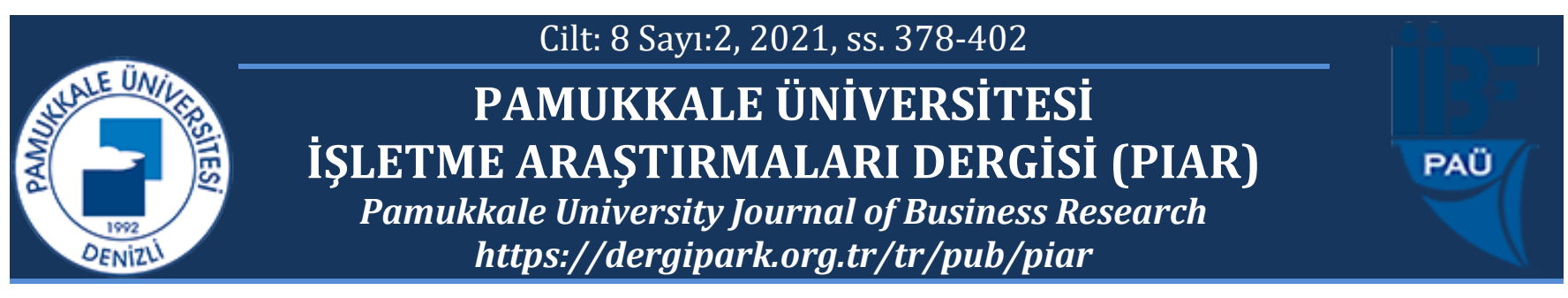

\title{
Tedarik Zinciri Yönetimi Uygulamalarının İşletme Performansına Etkisi: Gaziantep İli Örneği *
}

\author{
The Effect of Supply Chain Management Practices on Business Performance: \\ Example of Gaziantep City
}

\section{Zeynep ÖZGÜNER ${ }^{\text {** }}$}

Ali YILDIZ ${ }^{2}$

\author{
${ }^{1}$ Hasan Kalyoncu Üniversitesi, İktisadi, İdari ve Sosyal Bilimler Fakültesi, İşletme Bölümü \\ zeynep.ozguner@hku.edu.tr, https//orcid.org/0000-0002-8694-7275 \\ ${ }^{2}$ Yüksek Lisans Öğrencisi, Hasan Kalyoncu Üniversitesi, Lisansüstü Eğitim Enstitüsü, İşletme ABD, ali3146@msn.com, \\ https//orcid.org/0000-0003-1777-5657 \\ ** Yazışılan Yazar/Corresponding author
}

Makale Geliş/Received: 17. 092021

Makale Kabul/Accepted: 27. 10. 2021

\begin{abstract}
Öz
İşletmeler global pazardaki rekabet ortamında, bir yandan rekabetçi konumların korumak isterken diğer yandan da yeni müşterilerinin isteklerini yerine getirmede tedarik zinciri yönetimini uygulamaktadırlar. Küreselleşmeyle beraber artan rekabet ortamında tedarik zinciri yönetimi; işletmelerin performansların etkileyen etmenlerden birisi olarak görülmektedir. Tedarik zinciri yönetimi uygulamalarının işletmelerin performanslarmı doğrudan ya da dolayl olarak etkilediğ $i$ bilinmektedir. Bu etkinin boyutu ve anlamlılık düzeyinin araştırılması önemlidir. Bu bağlamda, çalışmanın amacı tedarik zinciri yönetimi uygulamalarının işletme performansına etkisinin araştırılması olarak belirlenmiştir. Araştırmada tedarik zinciri yönetimi ve işletme performansı ölçekleri kullanılarak oluşturulan anket Gaziantep ilinde üretim yapan 176 üretim işletmesine uygulanmıştır. Toplanan veriler SPSS ve AMOS programlarn ile analiz edilmiştir. Yapulan analizler sonucunda; tedarik zinciri yönetimi uygulamalarının işletme performansı üzerinde anlamlı ve pozitif yönde etkisinin olduğu bulgularna ulaşılmıştır.
\end{abstract}

Anahtar kelimeler: Tedarik zinciri yönetimi, tedarik zinciri yönetimi uygulamaları, işletme performansı JEL kodları: M1, M11, L23, L60

\begin{abstract}
Supply chain management in an increasingly competitive environment with globalization; It is seen as one of the factors affecting the performance of businesses. In the competitive environment in the global market, businesses want to maintain their competitive positions while implementing supply chain management in fulfilling the demands of their new customers. It is known that supply chain management practices directly or indirectly affect the overall performance of businesses. It is important to investigate the size and significance level of this effect. In this context, the purpose of this study was determined as the investigation of the effect of supply chain management applications on business performance. The questionnaire, which was created by using supply chain management and business performance scales in the research, was applied to 176 manufacturing companies in Gaziantep. The collected data were analyzed with SPSS and AMOS programs. As a result of the analysis made; It has been found that supply chain management practices have a significant and positive effect on business performance.
\end{abstract}

Keywords: Supply chain management, supply chain management practices, business performance JEL codes: M1, M11, L23, L60

\footnotetext{
* Bu çalışma, Ali Yıldız'ın "Tedarik Zinciri Yönetimi Uygulamalarının İşletme Performansına Etkisi: Gaziantep İlinde Bir Uygulama" başlıklı Yüksek Lisans Tezi'nden türetilmiştir.
} 


\section{GİRIŞ}

Globalleşme ile beraber artan rekabet ortaminda Tedarik Zinciri Yönetimi (TZY)'nin işletmelerin performanslarını üst noktalara çıkartan önemli bir faktör olduğu bilinmektedir. İşletmeler artık bir taraftan mevcut olan rekabetçi konumlarını korumak diğer taraftan ise müşterilerinin isteklerini yerine getirebilmek amacıyla tedarik zinciri yönetimini uygulamak zorundadirlar.

Tedarik zinciri yönetimi, hammaddenin bulunmasıyla başlayan ve bulunan hammaddeyle faydalı ve kar sağlayacak bir ürün üretilmesi ile devam eden, bu ürünü de nihai müşteriye ulaştırılmasına imkân veren ağın yönetimi şeklinde ifade edilebilmektedir.

İşletmeler, müşterilerini memnun etmek ve kendi performanslarını artırmak için içerisinde yer aldıkları zincirin üyeleriyle iş birliğini sürekli güçlü tutmaya ve geliştirmeye çalışmaktadırlar. Başarılı bir tedarik zinciri yönetimi; işletmelerde ürün kalitesini sürekli artırmayı, maliyetleri her zaman minimumda tutmayı, ürün esnekliğini ve dağıtım kanallarını sürekli geliştirmeyi, zincir üyeleri arasındaki bütünlüğü sağlayarak gerçekleştirebilmektedir.

Günümüzde işletmelerin bulundukları sektörde rekabet üstünlüğü sağlayabilmeleri için ana hedefleri, maksimum kalitedeki ürünleri minimum maliyetle elde etmek ve piyasadaki hızlı değişimleri iyi analiz ederken, süreçsel anlamda da esnek olabilme yeteneğinin geliştirilmesidir. Bu sayede yüksek düzeyde katma değer üretilerek özgün müşteri değeri oluşturulup, işletme performansını üst seviyelere taşımak daha mümkün hale gelmektedir.

Alan yazınındaki çalışmalar ışığında çalışmanın amacı tedarik zinciri uygulamalarından yaygın kullanımda olan faktörlerin işletme performansına etkisini ölçmektir.

Çalışmada işletmelerde yaygın olarak kullanılan tedarik zinciri uygulamalarının işletme performansına etkisi araştırılarak, tespit edilen bilgiler değerlendirilecektir. Bu doğrultuda işletmelere öneriler sunulması hedeflenmektedir.

\section{TEDARİK ZİNCİII YÖNETIMİ VE UYGULAMALARI}

Tedarik zinciri (TZ), malzemelerin hammadde olarak alınıp yarı mamul ve mamullere dönüştürülüp daha sonra bu ürünleri lojistik faaliyetleriyle en son müşteriye ulaştıran bir hizmet ve dağıtım ağıdır.

Tedarik zinciri yönetimini işletmelerin hammadde ve ara ürünleri satın aldığı, satın alınan bu ürünlerin son ürün haline getirildiği ve bu ürünlerin müşterilere ulaştırıldığ olarak tanımlamak mümkündür. Bu sistem tedarikçileri, üreticileri, dağıtıcıları, perakendecileri ve üretilen ürün veya hizmeti almak isteyen son müşteriyi bir araya getirmektedir. Tedarik zinciri yönetimiyle işletmeler kendilerini hem tedarikçileri hem de müşterileriyle bütün olarak düşünüp tek bir sistem gibi yönetmektedir. $\mathrm{Bu}$ sayede ürün/hizmet ve bilgi akışı tam zamanında gerçekleşmektedir (Şahin, 2019: 7).

İşletmelerin tamamını ilgilendiren tedarik zinciri yönetimi bu yapısından dolayı tek bir işletme gibi hareket edip, elindeki kaynakları etkin bir şekilde kullanarak ortak bir güç oluşturmaktadır. Bundan dolayı müşterinin siparişlerini düşük maliyetle, kısa zamanda ve müşterinin istediği şekilde teslim ederek kazançlı çıkılmaktadır. 
İşletmelerin hedeflerini tamamlaması; organizasyon evresinin ve işletmenin iç ilişkilerinin birbirleriyle uyumuna bağlıdır. Tedarik zinciri yönetimindeki halkaların her biri kendini ileriye taşımaya çalışmaktadır. Müşterilere sunulan mal ve hizmetlerle müşterinin isteğini tam olarak karşılamaya özen gösterilmektedir. Bunun amacı müşterinin isteklerini karşılamak ve müşteri memnuniyetini en üst seviyede tutmaktır (Urk, 2016: 30).

Müşteriler isteklerini birçok yoldan karşılamaktadır. Bu nedenle minimum girdiyle maksimum çıktı elde etmek çok önemlidir. TZ'de işletmeler dağıtım probleminden kurtulmaya ağırlık verirler. Buna rağmen piyasanın sürekli yenilenmesi, stoklarında mal bulunduran işletmeleri riskli ve güçsüz duruma düşürmektedir. Rakip işletmeler ürün ve hizmetlerine sürekli olarak katma değer eklemektedirler. Elde bulundurulan stokların maliyeti ürünlerin maliyetlerinde artış meydana getirmektedir.

TZY'nin en önemli özelliklerinden biri, zincirde bulunan işletmelerin faaliyetlerinin tamamını kapsayacak bir plan yapması ve böylece tüm işletmeleri ortak bir alanda toplanmasına imkân vermesidir. Bu şekilde işletmelerde iş ortaklığı ve sıkı iletişimin sonucunda hız, kalite, güvenirlilik ve maliyet gibi konularda bütün üyeler kazanım sağlamaktadır (Çağlıyan, 2009: 108).

Tedarik zinciri yönetimindeki her halka bu amaca yoğunlaştığından gereksiz olarak sık sık tekrarlanan eylemlerin sayılarında önemli bir düşüş yaşanacaktır. Bundan dolayı işletmelerin gereksiz işlem maliyetleri azalacak ve zaman tasarrufu sağlanacaktır. Tedarik zinciri elinde topladığı bilgileri zincirdeki diğer ortaklarla paylaşarak arz ve talep dengesini mükemmel bir şekilde sağlayacaktır.

Tedarik zincirinin en iyi şekilde işletilmesi ile kısa dönemde öncelikli olarak stoklar azaltılmış ve müşteriye daha hızlı dönüş sağlanmış olur. Stratejik amaç olarak uzun dönemde istenilen miktarda ve istenilen yerde teslim edilen ürünler ile müşteri isteklerini tam anlamıyla karşılamak ve işletmenin pazardaki payını artırarak karlılığını artırmaktır (Erdem, 2013: 18-19).

Alan yazınında daha önce çalışılan uygulamalardan bazıları şu şekilde sıralanabilmektedir (Toptanc1, 2013: 68): tedarikçileri stratejik planlamaya davet etmek, erteleme ve tedarikçiler ile ortak hedefleri ve stratejileri geliştirmek (Aydemir, 2000), tedarikçi seçim kriterleri ve tedarikçi performansı (Ungan, 2011), müşteri ilişkileri ve erteleme (Yön, 2007), satın alma (Kazançoğlu, 2008), bilgi paylaşma, satın alma, depolama, erteleme, Müşteri İlişkileri Yönetimi (MIY) ve Stratejik Tedarik Ortaklığı (STO) (Toptanc1, 2013) gibi faaliyetlerinin tedarik zinciri yönetimi uygulamaları arasında yer aldığı görülmektedir. Araştırma tedarik zinciri yönetimi uygulamalarından MIY, STO, tedarikçi seçimi, bilgi paylaşımı ve erteleme uygulamaları ile sinırlandırılacaktır.

Tedarik Zinciri Yönetimi Uygulamaları, çalışma kapsamında şu şekilde ifade edilmektedir:

\subsection{Müşteri İlişkileri Yönetimi (MİY)}

Tedarik Zinciri Yönetimi Uygulamaları (TZYU), tedarik zincirini etkili olarak yönetebilmek için bir örgütte üstlenilen faaliyetlerin bütünüdür (Ungan, 2011: 309). Müşteri ilişkileri yönetimi (MIY), müşterilerle iş yapmayı uzun vadede en karlı noktaya taşımaya çalışan bir yaklaşımdır (Civelek, 2016: 238). Müşteriler/tüketiciler artık daha karmaşık ve değişken isteklerde bulunmakla birlikte fikirlerini kendilerine daha çok değer kattığını düşündükleri 
hizmet ve ürün seçeneklerinden yana kullanmaktadırlar. Günümüzde işletmelerin önemle üzerinde durdukları noktalardan biri, mevcut müşterileri elde tutmak ve bunun yanında potansiyel müşterileri de mevcut müşteriler haline getirmektir (Özilhan, 2010: 22).

MìY üç temel bileşenden meydana gelmektedir. Bunlardan ilki insandır. Müşterilerin istek ve beklentilerini belirlemek ve bu istek ve beklentileri karşılayacak şekilde her müşteriye özel çözümler üretmektir. Bu bileşenlerden ikincisi süreçtir. Personelin aktardığı müşteri beklentilerini etkin ve hızlı süreç düzenlemesiyle müşteri merkezli bir yapıya dönüşümünü sağlar. Bu bileşenlerin üçüncüsü ise teknolojidir. Müşteri bilgilerini işletme içerisinde tüm süreç boyuna yönetebilen ve bununla birlikte işletmenin müşterilerinin yeni isteklerine de çözüm üretebilen teknolojik alt yapıyı sunmaktır. MiYY bir birimin ya da bir personelin işi olmayıp tüm işletmenin tüm birimlerinin katılımını gerekli kılan bir takım işidir (Urk, 2016: 59).

MİY'in faydalarını müşteri ve işletme açısından ikiye ayırabiliriz:

Müşteri açısından müşteri ilişkileri yönetiminin yararları; müşterilerin zaman harcayacak işlemlerden uzaklaşarak asıl görevlerine daha fazla zaman ayırmalarını sağlamaktadır. Zamanlarını düzenli kullandıklarında verimlilik artmaktadır. Müşterinin işletmeye giderek öğreneceği bilgiyi işletmenin web sitesinden öğrenmesi örnek verilebilir. Bunun yanında müşteriler daha ucuza daha kaliteli mal ya da hizmet alabilir. Satış öncesi ya da satış sonrasında yapılmakta olan faaliyetler ile müşterilerin kalite standartları yüksek hizmet ve ürünlere ulaşmasını sağlayarak, faydalarının maksimuma çıkarılması veya maliyetlerin minimuma indirilmesi ile özetlememiz mümkündür (Korkmaz, 2010: 26).

MIY stratejileri bir yandan müşteri sadakatini ve devamlılı̆̆ını iyileştirmekte diğer yandan da iş süreçlerinin geliştirilmesine katkı sağlamaktadır. MiY bir yandan işletmelerin en iyi müşterilerini tespit etmelerine yardımcı olmakta diğer yandan da daha açık ve ölçülmesi mümkün hedefler aracılığıyla pazarlama süreçlerinin yönetilmesine katkıda bulunmaktadır (Rahimı, 2013: 10).

\subsection{Stratejik Tedarik Ortaklığ}

İşletmeler yaşam sürelerini ve rekabet güçlerini artırmak için biçimsel ya da biçimsel olmayan legal ya da fiili sınırlar içerisinde bir araya gelerek işletme bazında sahip oldukları bilgilerini ve kaynaklarını birleştirme gereksinimi duymaktadırlar. Dolayısıyla işletmeler bu şekilde ortaklık ilişkisi kurarak bir rekabet gücü meydana getirmektedirler. İşletmelerin yapmış olduğu dayanışma, iş birliği ve kaynak birleştirme faaliyetlerinin geneline stratejik ortaklık adı verilmektedir (Aydıntan, 2003: 139).

Stratejik ortaklık, uzun süre beraber çalışmayı, birlikte plan yapmayı ve işletmelerin problemlerine beraber çözüm bulmayı sağlar. Bu ortaklık, işletmeler arasında stratejik olan, teknoloji, pazar ve ürün gibi alanlardaki faydaları paylaşmayı teşvik etmektedir (Yayla ve Ungan, 2019: 6).

Stratejik tedarikçi ortaklığı, üretilen ürünlerin pazarda tutması için sorumluluk yüklenmeye razı olan az sayıdaki tedarikçinin ortaklıklarla daha verimli çalışmalarına imkân verir. Ürün tasarımlarına katkı sağlayan tedarikçiler daha maliyetin etkin olduğu tasarım alternatifleri sunabilir, en uygun bileşenleri ve de teknolojiyi seçmelerine ve bunun yanında tasarımları değerlendirme konusunda yardımcı olabilirler. Önemli ortaklığı olan işletmeler birbirleriyle 
daha yakın ilişki içerisinde bulunabilirler ve bunun sonucunda boşa harcanacak emek ve zamanın önüne geçmiş olabilirler (Yayla ve Ungan, 2019: 6).

İşletmelerin sahip oldukları yetenekler ve kaynaklar rekabet avantajı sağlamada ve yaşam sürelerini uzun süre devam ettirebilmelerinde çok önemlidir. Kaynaklar, yetenekler ve işletmeyi meydana getiren unsurlar ya da bu unsurların kullanımı bakımından yetersiz olabilmektedirler.

İşletmelerin stratejik ortaklık yapma sebepleri temelde üç sebepten kaynaklanmaktadır; bunlardan ilki, işletmenin tek başına geliştiremediği tamamlayıcı ürün ve hizmetleri diğer işletmelerden almak durumunda kalmalarıdır. İkincisi, işletmeye gerekli olan yetenek ve kaynakları bir araya getirerek işletmenin değerini artırmak. Üçüncü neden ise, diğer işletmelerden yeni beceriler yetenekler öğrenerek işletmenin değerine değer katmaktır. Kurulan bu ittifaklar işletmenin eksiklerini giderme, öğrenen bir işletme olma ve kaynak kullanımı bakımından değerlidir. İşletmeler bu stratejik ortaklıkları kendi başlarına ulaşamadıkları amaçlarına ulaşmak için bir araç olarak kullanmaktadırlar (Demir ve Oktay, 2010: 2-3).

\subsection{Tedarikçi Seçimi}

Günümüzde sürekli gelişen teknolojisi ve ürün alternatifleriyle birlikte ürünlerin özelliklerinde önemli oranda gelişme sağlanmıştır. Ürünlerin parça sayılarında meydana gelen artış işletmeleri parça üretiminden parça tedarikine yönlendirmiştir. Bu durum ürün ya da hizmet sunan kişilere verilen tedarikçi kavramının gündeme gelmesini sağlamıştır. Tedarikçi, en iyi kalitede ve uygun fiyattaki ürün ve hizmeti en iyi şekilde organize eder. Tedarikçiler en iyi ürün ve hizmette maliyetin düşürülmesi, en iyi ürün ve hizmetin tasarlanması ve kalitenin daima arttırılmasını sağlayarak üreticinin performansını her zaman yüksek tutar (Acar ve Köylüoğlu, 2020: 421). Tedarikçi seçimini tanımlamak gerekirse; üretimde kullanılacak hammadde, yarı mamul ve diğer gerekli malzemelerin ne kadar ne zaman ve hangi tedarikçiden alınacağının belirlenmesidir (Günal, 2010: 12).

Tedarikçi seçiminin amacı, uzun vadede alıcı-tedarikçi ilişkilerini güçlendirip işletmelerin rekabet güçlerini artırmaktır. Tedarikçi seçimi, bir işletmenin ihtiyaçlarını en iyi şekilde ve maliyet olarak işletmeye en uygun maliyetle karşılayan tedarikçinin seçimini amaç edinmektir. Tedarikçi seçimi birçok kriter kullanılan bir süreçtir ve işletmeler için stratejik öneme sahiptir (Demirtaş ve Akdoğan, 2014: 207).

\subsection{Bilgi Paylaşımı}

Bilgi paylaşımı, tedarik zinciri ortakları için önemli olan bilgilerin paylaşımı ile ilgilidir. Bilgi paylaşımı, tedarik zincirindeki sorunları çözmeye yöneliktir ve tedarik zincirinin etkinliğini artıran önemli bir unsurdur. Bilgi alışverişi birimler arası koordinasyon için çok önemlidir (Gilanlı vd., 2019: 55).

İşletmeler arası bilgi paylaşımı, tedarik zincirindeki ortaklar arasındaki bilgi kazanımı olarak gösterilebilir. Ortak işletmeler kendi çevrelerini, kendi kurallarını ve olanaklarını kullanarak kendi bilgilerini oluşturabilirler (Çemberci vd., 2015: 143).

İşletmeler arasındaki bilgi paylaşımı işletmelerin performanslarını artırmaktadır. Paylaşılan bilgi çeşitleri, sipariş oranları, tahminlerin doğruluğu, stok seviyeleri, satış dataları ve 
siparişlerin zamanında teslimidir (Gilanlı vd., 2019: 55). Bazı araştırmalara göre işletmeler arası bilgi paylaşımının birçok avantajı vardır. Bu avantajlardan bazıları; stokları azaltma ve iyi stok yönetimi, maliyetleri azaltma, belirsizliklerin azaltılması, kurumsal verimlilik ve daha iyi hizmet sunumu, genişletilmiş şebeke ağı, optimum düzeyde kapasite kullanımı (Şahin, 2018: 31), müşteri beklentilerine daha hassas olma, müşteri beklentilerini daha kısa sürede cevap verme (Çemberci vd., 2015: 144), artan üretim, örgütsel verimlilik, işletmeler arası sosyal bağların kurulması ve geliştirilmesi, sorunları önceden tespit etme, siparişlere zamanın da cevap verme, pazara en iyi zamanda girme (Gilanlı vd., 2019: 55) şeklinde siralanabilir.

Tedarik zinciri yönetimi, bütün pazarlama, ürün çeşitlendirme, satış, finans ve bilgi teknolojilerinin haricinde lojistik ve üretim faaliyetlerini de içine katarak bu süreçlerin düzenli bir şekilde yönetilmesini sağlamaktadır. Bu yönetimin sağlanmasında aşağıdaki üç önemli akış bulunmaktadır (Koçoğlu, 2010: 61).

1. Fiziksel Akış: bu akış tek yönlüdür (tedarikçiden müşteriye olacak şekilde).

2. Finansal Akış: müşteriden satıcıya olan akıştır.

3. Bilgi Akışı: Tedarik zinciri ortakları arasında karşılıklı olarak sağlanan bir akıştır.

TZY' de koordinasyon ancak işletmeler arasında bilgi paylaşımının olması halinde sağlanmaktadır. Paylaşılan bu bilgiler üretim, programlama ve stok kontrolleri için çok önemlidir. TZY içerisinde bilgi paylaşımı eksikliğinden kaynaklanan tedarik zincirinin alt birimlerinden üst birimlerine doğru talep bildirimlerinde miktar değişikliği görülmektedir. Bu değişikliklerin adına "kamçı etkisi" denmektedir (Urk, 2016: 79).

TZ üyeleri arasındaki bilgi akışında oluşabilecek bilgi çarpıklığı, zaman ve enerjinin gerektiği şekilde kullanılamamasından kaynaklı aşırı bir şekilde stok yatırımları, verimsiz müşteri servisleri, kar kayıpları, gelir kayıpları, kapasite planlarında sapma, uyulmasında zorluk çekilen üretim tabloları gibi verimsizlikler meydana gelmektedir (Paksoy ve Keskin, 2006: 484).

\subsection{Erteleme}

Erteleme, ilk olarak Alderson tarafından ortaya çıartılan ve daha sonra ise Bucklin tarafından geliştirilen bir kavramdır. Bu kavram üretim süreci ve fiziksel olarak dağıtım sürecinde gerekli olan en son yerde ürünlerin şeklini, bilgilerini veya yerini değiştirmenin bir yolu olarak görülmektedir (Ferreira vd., 2014).

Tedarik zincirindeki birimlerden bazılarının ürün çeşitliliğiyle ilgili risk taşımak zorunda olacağ1 ve ertelemenin bu riski sadece bir birimden diğer bir birime aktaracağı ileri sürülmektedir. Ancak imalat işletmeleri, geleneksel yöntem olan stok için üretme yönteminden siparişe göre üretim yöntemine geçtiklerinden erteleme, bu işletmeler için çok avantajlı bir yöntem olmuştur (Urk, 2016: 81). Tedarik zinciri yönetiminde kullanılabilecek farklı erteleme tipleri bulunmaktadır. Bunlar; etiketleme, paketleme, montaj, imalat ve zamanla ilgili ertelemelerdir (Ferreira vd., 2020).

Ferreira vd. (2014)'ne göre imalat ve lojistik olmak üzere iki tip erteleme vardır. İmalat ertelemesi, ürünleri üretip stoklarda bekletmek yerine tüketiciden nihai ürünün özelikleri gelene kadar ertelenir. Lojistik ertelemesi, işletmelerde üretilen nihai ürünleri bir merkezde 
bekletmeyi kapsamaktadır. Bu yöntemle stoktaki ürünlerin yer değiştirmesi müşterinin sipariş vermesine kadar ertelenmektedir. Sipariş oluştuğunda ürün müşteriye gönderilmektedir.

Erteleme stratejisi, envanter eskimesi durumunu etkin olarak azaltmakta ve istenmeyen ürünlere sahip olma ile bağlantılı risk ve belirsizlik maliyetlerini ortadan kaldırmaktadır. Ancak bu strateji kendi müşterileri için doğru ürünler üretmek yada tahsis etmek için tedarik zinciri aracılığıyla yaygınlaşmayı sağlamaya yönelik entegre ve çevik bir tedarik zinciri gerektirmektedir. Erteleme stratejisinin işletmelere kazandırdıkları şu şekilde sıralayabiliriz (Urk, 2016: 84):

Müşterilerin beklentilerine göre ürünlerin üretiminin tamamlanması ve böylelikle müşteri memnuniyetini sağlamak. Tedarik zinciri yönetimi süreci içerisinde stoktaki ürünlerin azaltılmasıyla fiyat dalgalanmasından kaynaklanacak olan zarardan korunmak ve stok maliyetlerini azaltmak. Stok için üretme politikasından müşteri talebi için üretme politikasını benimsemek böylece pazar trendini yakalayarak karlılığı yükseltmek.

Sonuç olarak, erteleme stratejisinin ürün çeşitliliğinin, talep belirsizliğinin ve ürün birim değerinin yüksek olduğu, bununla birlikte ürün yaşam süresinin de kısa olduğu sektörlerde uygulanmasının başarılı sonuçlar doğuracağı düşünülmektedir. Elektronik ve giyim sektörlerinde bu görülmektedir (Toptanc1, 2013: 78).

\subsection{Literatür Çalışması}

Öztürk ve Tekin'in (2020) çalışmaları kapsamında Ankara'da faaliyet gösteren 90 gıda işletmesinde kolayda örnekleme yöntemiyle veriler toplanmıştır. Çalışmada uygulanan korelasyon analizi neticesinde TZY ile işletme performansı arasında pozitif yönlü ve anlamlı bir ilişki olduğunu tespit edilmiştir. Bunun yanında yapılmış olan regresyon analizi sonucuna göre ise işletme performansında meydana gelen değişimin \%71'inin TZY' den kaynaklandığ tespit edilmiştir.

Urk (2016) TZYU' nın TZY performansı ve işletme performansına etkisini tespit etmek amacıyla yapmış olduğu çalışmada, TZYU' nın TZY performansı ve işletme performansını artırdığ1 yönünde olumlu etkiler olduğuna yönelik bulgulara ulaşmıştır.

Güçlü (2010) yapmış olduğu tez çalışmasında, turizm sektöründe faaliyette bulunan 3, 4 ve 5 yıldızlı otellerde tedarik zinciri yönetimi boyutlarının işletme performansı üzerine etkisini araştırmıştır. Bu araştırma sonucunda TZY boyutlarından yenilikçilik, rekabetçilik, kurumsal gelişime katkı, ilişki gücü ve müşteri ilişkileri boyutlarının İşletme Performansı (İP)'nı pozitif etkilemediği ancak hız ve esneklik boyutunun İP'i pozitif yönde etkilediği bulgularına ulaşmıştır.

Yağ $\mathrm{c}$ (2009) 'nın çalışması ile Ege bölgesinde faaliyette bulunan dört ve beş yıldızlı oteller ve birinci sınıf tatil köylerinden anket yöntemiyle veri toplanmıştır. Müşteri ilişkileri veri tabanından alınan bilgiler ve uygun malzemelerin tedariki ile maliyetlerin azaltılması, müşteri memnuniyetinin sağlanması ve genel işletme performansının artıp artmadığının tespit edilmesi amaçlanmaktadır. Araştırmalar sonucunda müşteri ilişkilerinin, konaklama işletmelerinin genel performansı üzerinde etkili olduğu sonucuna ulaşılmıştır. 
Civaroğlu (2006) Trakya Bölgesi'nde yaptığı çalışması ile TZYU' nın ilaç sektöründe faaliyet gösteren işletmelerin performanslarına olan etkilerinin ampirik olarak tespit etmeyi amaçlamış, çalışma sonucunda TZYU' nın işletme performansına anlamlı katkılarının olduğu tespit edilmiştir.

Alan yazın araştırmasında da görüldüğü üzere tedarik zinciri uygulamalarının işletmelerin performansları üzerinde önemli etkileri bulunmaktadır. Özellikle işletmelerin başarısının tedarik zincirinin diğer halkalarına bağlı olduğu günümüz rekabet koşullarında bu zincirin başarını artıracak yönetsel uygulamaların performans üzerinde oluşturduğu etkiyi ölçmek gerek tedarik zinciri gerekse de işletmeler açısından büyük önem taşımaktadır. Bu açıdan çalışmanın, sonuçları itibariyle önem taşıdığı düşünülmektedir.

\section{METODOLOJi}

Tedarik zinciri yönetiminin değişkenleri; tedarikçi gelişimi, stratejik tedarikçi ortaklı̆̆ı, müşteri ilişkileri yönetimi (MiY), bilgi paylaşımı ve erteleme olarak belirlenmiştir. Çalışmanın amacı doğrultusunda ve literatüre dayandırılarak oluşturulan hipotezler aşağıdaki gibi sıralanmaktadır:

$\mathrm{H}_{1}$ : TZYU' nın işletme performansına pozitif ve anlamlı bir etkisi vardır.

$\mathrm{H}_{2}$ : TZYU'nın alt boyutlarından bilgi paylaşımının işletme performansı üzerinde pozitif ve anlamlı bir etkisi vardır.

$\mathrm{H}_{3}$ : TZYU'nın alt boyutlarından tedarikçi gelişiminin işletme performansı üzerinde pozitif ve anlamlı bir etkisi vardır.

$\mathrm{H}_{4}$ : TZYU'nın alt boyutlarından stratejik tedarikçi ortaklığının işletme performansı üzerinde pozitif ve anlamlı bir etkisi vardır.

H5: TZYU'nın alt boyutlarından müşteri ilişkileri yönetiminin işletme performansı üzerinde pozitif ve anlamlı bir etkisi vardır.

H6: TZYU'nın alt boyutlarından ertelemenin işletme performansı üzerinde pozitif ve anlamlı bir etkisi vardır.

Çalışmanın amacı doğrultusunda oluşturulan araştırma modeli şu şekildedir;

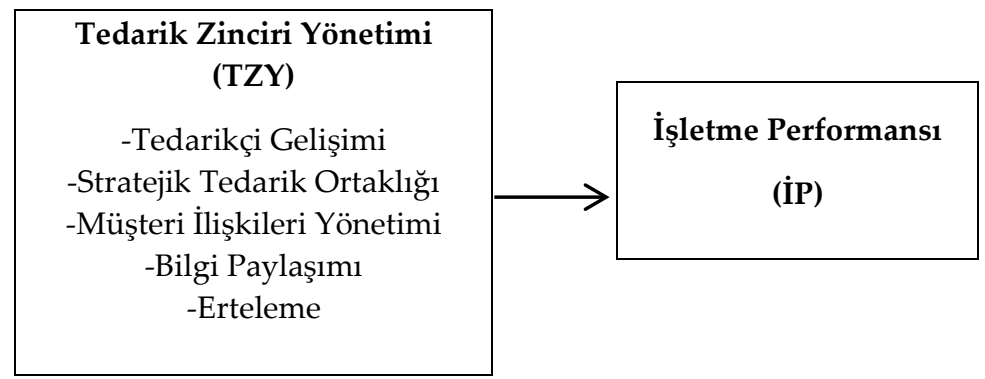

Şekil 1. Araştırmanın Modeli

Araştırmanın evrenini; Gaziantep ilindeki OSB'lerde bulunan 1100 üretim işletmesi oluşturmaktadır. Evrende \%95 güven aralığında ve \%5 hata payına göre örneklem büyüklügünün en az 254 olması gerekmektedir (Gürbüz ve Şahin 2016, 132). Ancak pandemi kısıtlamaları, ilgili yöneticilerin işletmede bulunamaması veya anketi cevaplamak 
istememeleri gibi nedenlerden dolayı 176 üretim işletmesinin verileri analize tabi tutulmuştur.

Araştırma kapsamında hazırlanan ölçek işletmelerde bulunan üst düzey yöneticilere ve tedarik ve lojistik sorumlusu olan orta düzey yöneticilere uygulanmıştır. Araştırmanın örneklemi belirlenirken basit tesadüfi örneklem yöntemine başvurulmuştur. $\mathrm{Bu}$ yönteme sayesinde belirlenen evren içerisindeki tüm üretim işletmelerine eşit düzeyde örnekleme girme şansı verilmektedir. Ayrıca küçük ölçekli evrenler için en işlevsel yöntemlerden biridir (Gürbüz ve Şahin, 2016: 138).

Anket ölçeği üç bölümden oluşmaktadır. Bunlar; Tedarik Zinciri Yönetimi Ölçeği, İşletme Performansı Ölçeği ve demografik bilgilerdir.

Araştırma kapsamında kullanılan Tedarik Zinciri Yönetimi Ölçeği Urk (2016) tarafından doktora çalışmasında kullanılmıştır. Ölçek sekiz boyuttan ve 32 ifadeden oluşmaktadır. Ancak çalışma kapsamında ölçeklerin geçerliliklerinin belirlenmesi amacıyla yapılan Keşfedici Faktör Analiz sonucunda ölçeği oluşturan ifadelerin 5 boyut altında toplandığ görülmüştür. Bu duruma düşük faktör yüküne sahip veya çapraz yüklenme sorunu olan ifadelerin ölçekten çıkarılmasının neden olduğunu söylemek mümkündür. Bu durumun Ortaya çıkan boyutlar; Müşteri İlişkileri Yönetimi, Stratejik Tedarikçi Ortaklığı, Tedarikçi Gelişimi, Bilgi Paylaşımı ve Erteleme şeklinde adlandırılmıştır.

İşletme performansı ölçeği literatürde uygulanan, güvenilirliği ve geçerliliği kanıtlanmış (Cronbach's Alpha=0,908) bir ölçektir. Araştırmalar sonunda Özgüner (2017) tarafından doktora çalışmasında kullanılan işletme performansı ölçeğinin tamamı çalışmamızda kullanılmak üzere anket formuna alınmıştır. İşletme performansı ölçeği tek boyuttan oluşmaktadır. Ölçek 15 sorudan meydana gelmektedir ve işletmelerin genel performanslarını ölçme amaçlanmaktadır.

Araştırmada kullanılan tedarik zinciri yönetimi ölçeği ve işletme performansı ölçeğinin uygulanması sonucu elde edilen veriler SPSS programına yüklenecek şekilde kodlanarak programa yüklenmiş. SPSS ve AMOS programları ile istatistiksel analizler yapılmıştır.

Açıklayıcı Faktör Analizi (AFA) uygulanmıştır. TZY ölçeği analiz sonunda beş boyutlu olduğu tespit edilmiştir. İP ölçeği analiz sonunda tek boyutlu olduğu tespit edilmiştir.

Yapılan Doğrulayıcı Faktör Analizi (DFA) analizinden elde edilen bulgulara göre,

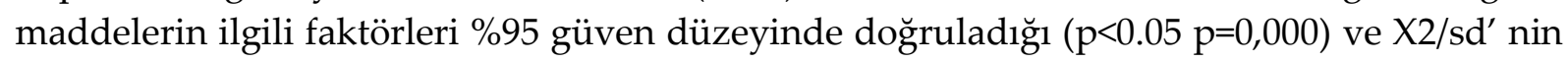
ve diğer uyum kriterlerinin mükemmel uyum aralıklarında olduğu belirlenmiştir. Regresyon analizi uygulanmıştır. Çalışmadaki ölçekler arası ilişki düzeyini incelemek amacı ile korelasyon analizi uygulanmış ve bulgular yorumlanmıştır.

\section{UYGULAMA}

Tedarik zinciri yönetimi uygulamalarının işletme performansına etkisini araştırmak üzere Gaziantep ilindeki OSB'lerde bulunan üretim işletmelerinden toplanan veriler analiz edilmiş ve bulgular aşağıdaki gibi ifade edilmiştir. 


\subsection{Normallik Testleri}

Çalışmada uygulanan, ölçekleri oluşturan verilerin normal dağılıp dağılmadığının tespit edilmesi için normallik testleri yapılmıştır. Sosyal bilimlerde çalışmaların normallik testinde en çok kullanılan yöntem olan çarpıklık ve basıklık verileri değerlendirilmiştir. Medrano vd. (2014: 552)' ne göre basıklık ve çarpıklık değerleri +3 ve -3 arasında ise verilerin normal dağılım aralığında olduğu varsayılmaktadır.

Tablo 2. Alt Boyutların Basıklık ve Çarpıklık Değerleri

\begin{tabular}{ccccccc}
\hline & Min & Max & Ort. & Std. Sapma & Çarpıklık & Basıklık \\
\hline Bilgi Paylaşımı & 1,13 & 5,00 & 3,89 &, 61 & $-1,368$ & 3,901 \\
\hline Müşteri İlişkileri Yönetimi & 1,20 & 5,00 & 4,47 &, 61 & $-2,830$ & 10,971 \\
\hline Erteleme & 1,00 & 5,00 & 2,38 & 1,26 &, 249 & $-1,185$ \\
\hline Tedarikçi Gelişimi & 1,00 & 5,00 & 2,13 & 1,39 &, 741 & $-1,065$ \\
\hline Stratejik Tedarikçi Ortaklığ1 & 2,00 & 5,00 & 3,77 &, 72 &,- 205 &,- 448 \\
\hline Tedarik Zinciri Yönetimi Uygulamaları & 1,95 & 4,82 & 3,56 &, 52 &,- 030 &, 165 \\
\hline & 1,62 & 4,92 & 3,47 &, 62 &,- 491 &,- 519 \\
\hline
\end{tabular}

Tablo 2 incelendiğinde tedarik zinciri yönetimi uygulamaları, tedarikçi gelişimi, stratejik tedarikçi ortaklığı, erteleme ve işletme performansı değişkenlerinin basıklık ve çarpıklık değerleri -3 ile +3 değerleri arasında olduğu görülüyor. Kalaycı (2008: 6)'ya göre çarpıklık ölçüsünün +3 ile -3 aralığında değerler alması durumunda da verilerin normal dağıldığı kabul edilmektedir. Bilgi paylaşımı ve müşteri ilişkileri yönetimi alt boyutlarının normal dağılıma sahip olmadığı görülmektedir. Fakat, sosyal bilimler alanının doğası gereği verilerin çoğunlukla normal dağılıma sahip olmadığı yapılan araştırmalarla ortaya konulmuştur. Normal dağılım göstermeyen verilerle ulaşılacak sonuçların normal dağılıma sahip verilerle elde edilecek sonuçlardan farklı olmayacağı vurgulanmıştır. Yapılan çalışmalar farklı basıklık ve çarpıklık değerlerine sahip veriler üzerinden yapılan Yapısal Eşitlik Modeli analizi sonuçlarının büyük farklılıklar göstermediğini ortaya koymuştur. Bu nedenle sosyal bilimler alanında yapılan bilimsel çalışmalarda normal dağılım varsayımının katı bir şekilde aranmaması kabul edilebilir bir durumdur (Gürbüz ve Şahin, 2016: 219).

\subsection{Geçerlilik, Güvenirlik ve Faktör (Açıklayıcı ve Doğrulayıcı Faktör) Analizi}

TZYU Ölçeğinin geçerlilik ve güvenilirlik analizlerine ait veriler elde edilmiştir. Tedarik zinciri yönetimi uygulamaları ölçeğinde madde analizi sonuçlarına bakıldığında, bir maddenin diğer maddelerle olan ilişkisinin 0,25 ' in altında olmaması gerektiği için, tedarik zinciri yönetimi uygulamaları ölçeğinden 5,6,7 nolu maddeler ölçekten çıkarılmıştır (Gürbüz ve Şahin, 2016: 312). Geriye 29 madde kalan ölçeğin yeni güvenirlik düzeyi sonuçları aşağıdaki tabloda verilmiştir. 
Tablo 3. Tedarik Zinciri Yönetimi Uygulamaları Ölçeğine İlişkin Güvenirlik Analizleri

\begin{tabular}{l|l}
\hline \multicolumn{1}{c|}{ Faktörler } & $(\boldsymbol{\alpha})$ \\
\hline Bilgi Paylaşımı & $\mathbf{0 . 9 0 9}$ \\
\hline Müşteri İlişkileri Yönetimi & $\mathbf{0 . 8 7 6}$ \\
\hline Tedarikçi Gelişimi & $\mathbf{0 . 9 1 3}$ \\
\hline Erteleme & $\mathbf{0 . 9 3 0}$ \\
\hline Stratejij Tedarikçi & $\mathbf{0 . 4 8 4}$ \\
\hline Tedarik Zinciri Yönetimi Uygulamaları Ölçeği (Genel) & $\mathbf{0 , 8 7 8}$ \\
\hline
\end{tabular}

Tablo 3'te tedarik zinciri yönetimi uygulamaları ölçeğine ilişkin güvenilirlik değerleri alt boyutlar halinde gösterilmektedir. Kalaycı (2008: 405)'ya göre güvenilirlik $0.60 \leq \alpha<0.80$ ise ölçeğin oldukça güvenilir olduğunu söylemek mümkündür. Tablo 3 'te de görüldüğü ölçeği oluşturan alt boyutların güvenilir olduğunu söylemek mümkündür.

Tablo 4'te görüldüğü üzere araştırmaya katılan işletmelerin bilgi paylaşım düzeylerinin iyi olduğu $(3,89)$, yine müşteri ilişkileri yönetimi düzeylerinin $(4,47)$ ve tedarikçi ortaklıklarının $(3,77)$ yüksek düzeyde olduğunu söylemek mümkündür. Bununla birlikte erteleme alt boyutunun $(2,38)$ ve tedarikçi gelişimi $(2,13)$ düzeylerinin düşük olduğunu söylemek mümkündür. $\mathrm{Bu}$ sonuç işletmelerde ertelemeden kaynaklı gecikmelerin az olduğunu ve tedarik zincirinin bu açıdan herhangi bir darboğaz yaşamadığını göstermektedir.

Tablo 4. Tedarik Zinciri Yönetimi Uygulamaları Ölçeğine İlişkin AFA Sonuçları

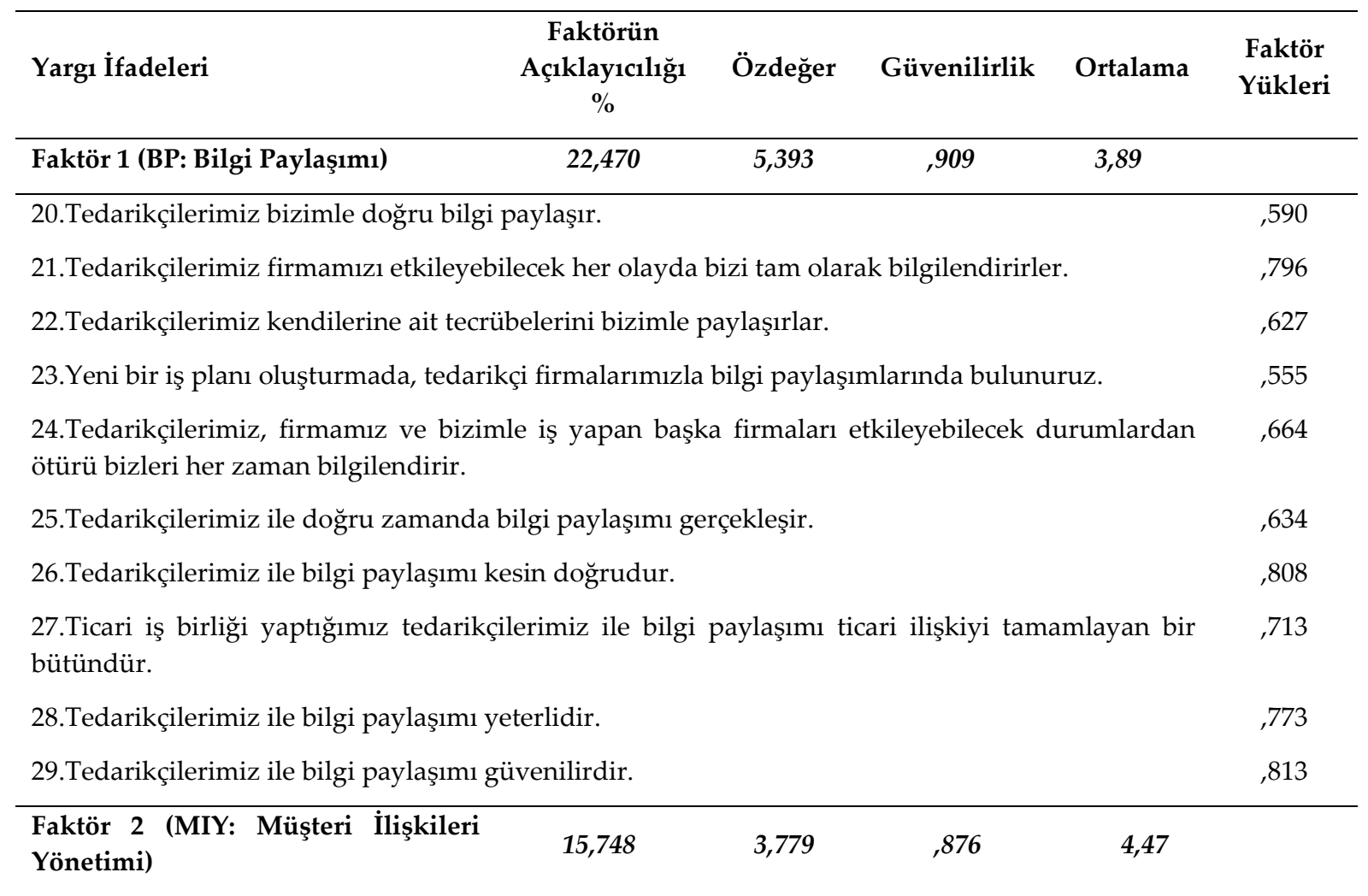


kısa sürede cevap verebilmektir.

15. Müşterilerimizin memnuniyeti sürekli gözlemler ve değerlendiririz.

16. Belli aralıklarla geleceğe yönelik müşteri beklentilerini belirleriz.

17. Müşterilerin bizden daha kolay yardım almalarını kolaylaştıracak adımlar atarız.

18. Periyodik olarak müşteri ilişkilerimizin firmamız için önemini gözden geçiririz.

\begin{tabular}{lccc}
\hline Faktör 3 (TG: Tedarikçi Gelişimi) & 12,913 & \multicolumn{2}{c}{, 913} \\
\hline 1. Firmamız tedarikçi firmanın teknik ve kalite becerilerini arttırmak için elaman istihdam eder. &, 848 \\
2. Firmamız mühendisleri tarafından tedarikçi firmalara düzenli saha ziyaretlerinde bulunur. &, 830 \\
3. Firmamız tarafından tedarikçilerimizin geliştirilmesi için ekipler oluşturulur. &, 829
\end{tabular}

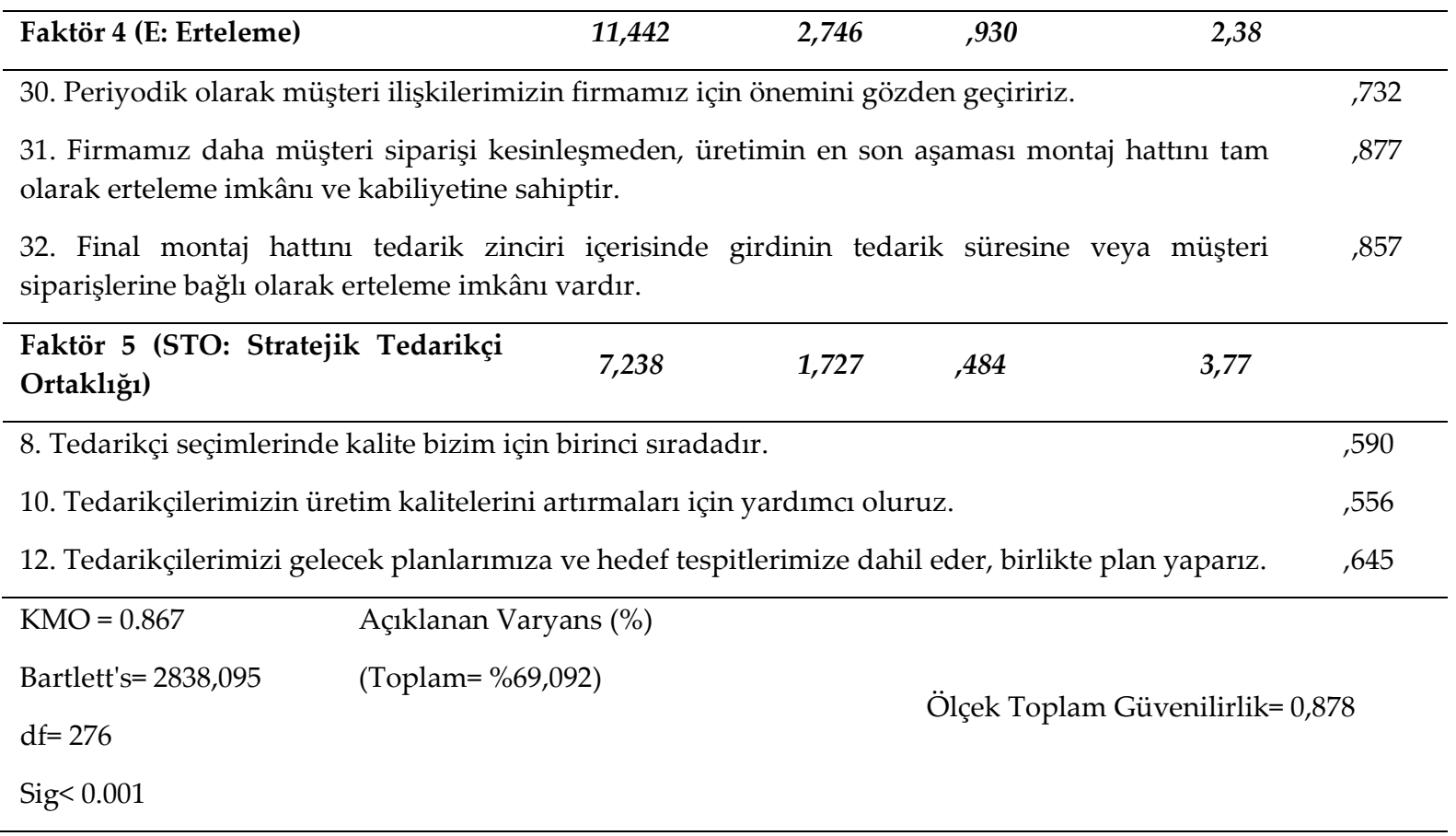

Ölçeği ve faktörleri oluşturan bütün değişkenlere ait faktör yükleri, alt sınırın $(0,30)$ üstünde olduklarından, iç tutarlılığın ve güvenilirliğin sağlandığı görülmüştür. Güvenilirlik analizine göre, 5,6,7 numaralı maddelerin ölçekten çıkarıldıktan sonra tüm soruların yer aldığı Açılayıcı Faktör Analizi sonuçlarına göre "Madde 4: Tedarikçi ile iş sonlandırılınca, tedarikçi satışlarını ve iş hacmini kolay bir şekilde başka alıcılarla telafi edebilir.", "Madde 9: Problemleri; genellikle tedarikçilerimiz ile işbirliği içinde çözmeye çalışırız.", "Madde 11: Sürekli gelişim programlarımızı kendi firmamızda olduğu gibi, anahtar tedarikçilerimizin de uygulamalarını isteriz.", "Madde 13: Anahtar tedarikçilerimizle yeni ürün geliştirme süreçlerinde aktif olarak birlikte çalışırız.", "Madde 19: Değişen piyasa şartları için ticaret ortaklarımızı (tedarikçilerimizi) önceden bilgilendiririz" madde yüklerinin iki faktör arasında en az 0.10 luk farklılık oluşturmaması sonucunda faktör analizinden çıkarılarak analizlere devam edilmiştir.

4, 9, 11, 13, 19. maddelerin ölçekten çıkarıldıktan sonra yapılan açıklayıcı faktör analizi sonucunda ölçeği oluşturan 24 ifadenin faktör yükleri 0.555 ile 0.877 arasında bulunmaktadır. Ayrıca KMO değerinin 0,867 olması ve Bartlett's testinin anlamlı sonuç 
vermesi, her bir boyut için toplanan verilerin araştırmada kullanılan ölçekle uyumlu bir şekilde faktörler altında toplanabileceğini ve araştırma konusu ile ilgili yazını desteklediğini göstermiştir. Araştırma modelinde bulunan beş faktörden, F1 (Bilgi Paylaşımı) toplam varyansın \%22,470' ini, F2 (Müşteri İlişkileri Yönetimi) \%15,748' ini, F3 (Erteleme) \%12,193' ünü, F4 (Tedarikçi Gelişimi) \%11,442' sini, F5 (Stratejik Tedarikçi Ortaklığı) \%7,238' ini açıklamaktadır.

Tablo 5. Tedarik Zinciri Yönetimi Uygulamaları Ölçeğine Ait DFA Sonuçları

\begin{tabular}{|c|c|c|c|c|c|}
\hline Ölçüm Adı & Mükemmel Uyum & Kabul Edilebilir Uyum & Modelin Ulaştı̆̆ sonuç & Modelin & Başarı \\
\hline & & & & & \\
\hline$\chi^{2 / \mathrm{df}}$ & $0<X^{2} / s d<3$ & $0<X 2 / s d<5$ & 2,342 & + & \\
\hline RMSEA & RMSEA $\leq .05$ & RMSEA $\leq .09$ & 0,088 & + & \\
\hline NFI & $.95 \leq \mathrm{NFI}<1.0$ & $.80 \leq \mathrm{NFI}<1.0$ & 0,813 & + & \\
\hline NNFI (TLI) & $\mathrm{TLI} \geq .95$ & $\mathrm{TLI} \geq .80$ & 0,863 & + & \\
\hline CFI & CFI $\geq .95$ & $\mathrm{CFI} \geq .80$ & 0,882 & + & \\
\hline
\end{tabular}

Schermelleh ve Moosbrugger, (2003)

Bir modelin kabul edilebilir uyum ya da mükemmel uyumda olduğunun belirlenmesinde kullanılan en önemli uyum kriterinin X2/sd' dir. (Schermelleh-Engel ve Moosbrugger, 2003). X2 önerilen model ile verinin uyumunu test etmektedir. Bu uyumun anlamsiz olmas1, önerilen model ile örneklem kovaryanslarının benzer olduğunu anlamına gelmektedir. X2/sd X2 değeri örneklemden etkilendiğinden dolayı serbestlik derecesine oranı daha güvenilir sonuçlar vermektedir. RMSEA Serbestlik derecesini de dikkate alarak modelin örneklem kovaryansı ile ne derece uyumlu olduğunu sunmaktadır. CFI; serbestlik derecesini ve örneklem büyüklügünü gör önüne alarak test edilen modeli temel modele göre karşılaştırmaktadır. NFI; CFI' dan farklı olarak X2 dağılımının gerektirdiği koşullara bağlı olmaksızın karşılaştırma yapmaktadır. TLI(NNFI); NFI'nın serbestlik derecesi dikkate alarak hesaplanmış halini ifade etmektedir. IFI; örneklem büyüklüğü ve modelin karmaşıklık derecesini dikkate alarak modelin uyumunu test etmektedir (Gürbüz, S. 2019: 34).

Ölçeğe ait RMSEA kriteri ilk aşamada istenilen düzeyde çıkmadığı görülmüştür. Bunun üzerine ölçeğin veri ile uyum iyiliğini yükseltmek maksadıyla DFA'nın Modifikasyon İndeksleri (MI) incelenmiştir. Bu kapsamda, uyum iyiliği değerlerinde en fazla iyileşme sağlayacağ 1 tespit edilen, birbiri arasındaki kovaryans değerlerinin yüksek olduğu belirlenen s21-s22, s28-s29, s17-s18 maddeleri arasında modifikasyon yapılmıştır. Modifikasyonlar, modelde orijinal olarak görülemeyen ancak ilgili düzenlemelerin yapılması yoluyla ki-kare miktarında meydana gelebilecek iyileşmeleri gösteren indekslerdir. Modifikasyonlar uyum iyiliği değerlerine ulaşılıncaya kadar devam ettirilebilir (Meydan ve Şeşen, 2015: 38; Özgüner, 2019: 74). Uygulanan DFA analizi sonucunda, maddelerin ilgili faktörleri \%95 güven düzeyinde doğruladığ1 $(p<0.05 p=0,000)$ ve $X 2 / s^{\prime}$ nin ve diğer uyum kriterlerinin mükemmel uyum aralıklarında olduğu belirlenmiştir. 
Tablo 6. Tedarik Zinciri Yönetimi Uygulamaları Ölçeğine Ait Regrasyon Katsayıları Tablosu

\begin{tabular}{|c|c|c|c|c|c|c|}
\hline & & & Estimate & S.E. & C.R. & $\mathrm{P}$ \\
\hline s18 & $<---$ & MIY & 637 & & & \\
\hline s17 & $<---$ & MIY & 774 & 136 & 10,417 & $* * *$ \\
\hline s16 & $<---$ & MIY & ,783 & 157 & 8,318 & $* * *$ \\
\hline s15 & $<---$ & MIY & ,825 & 169 & 8,602 & $* * *$ \\
\hline s14 & $<---$ & MIY & ,754 & ,150 & 8,097 & $* * *$ \\
\hline s30 & $<---$ & $\mathrm{E}$ & 820 & & & \\
\hline s31 & $<---$ & E & ,958 & ,066 & 16,591 & $* * *$ \\
\hline s32 & $<---$ & $\mathrm{E}$ & ,945 & ,066 & 16,342 & $* * *$ \\
\hline s1 & $<---$ & TG & ,838 & & & \\
\hline s2 & $<---$ & TG & ,895 & ,077 & 14,857 & $* * *$ \\
\hline s3 & $<---$ & TG & 911 & ,070 & 15,170 & $* * *$ \\
\hline s8 & $<---$ & STO & ,528 & & & \\
\hline s10 & $<---$ & STO & 684 & ,336 & 4,997 & $* * *$ \\
\hline s12 & $<---$ & STO & ,360 & ,300 & 3,517 & $* * *$ \\
\hline s29 & $<---$ & $\mathrm{BP}$ & 744 & & & \\
\hline s28 & $<---$ & $\mathrm{BP}$ & ,754 & ,074 & 12,496 & $* * *$ \\
\hline s27 & $<---$ & $\mathrm{BP}$ & 792 & 101 & 10,458 & $* * *$ \\
\hline s26 & $<---$ & $\mathrm{BP}$ & ,723 & 106 & 9,479 & $* * *$ \\
\hline s25 & $<---$ & $\mathrm{BP}$ & ,746 & ,098 & 9,801 & $* * *$ \\
\hline s24 & $<---$ & $\mathrm{BP}$ & 645 & 115 & 8,395 & $* * *$ \\
\hline s23 & $<---$ & $\mathrm{BP}$ & 603 & 140 & 7,816 & $* * *$ \\
\hline $\mathrm{s} 22$ & $<---$ & $\mathrm{BP}$ & 623 & 115 & 8,067 & $* * *$ \\
\hline s21 & $<---$ & $\mathrm{BP}$ & 763 & 121 & 10,044 & $* * *$ \\
\hline s20 & $<---$ & $\mathrm{BP}$ & 687 & 109 & 8,982 & $* * *$ \\
\hline
\end{tabular}

Yukarıdaki tablodaki verilere göre her bir ikili ilişki için " $p$ " değerleri 0,05'ten küçük olduğu için, faktör yüklenimleri önemlidir. Faktör yüklenimlerinin önemli çıkması maddelerin, faktörlere doğru yüklendiği anlamına gelmektedir (Karagöz, 2017: 481-482). Bunun sonucunda tedarik zinciri yönetimi uygulamaları ölçeğinin doğrulayıcı faktör analizi yapısı açıkça görülmektedir (Tablo .6).

Tedarik zinciri yönetimi uygulamaları alt boyutlarından Bilgi Paylaşımı (BP) boyutunda en etkili değişkenin 0,792'lik katsayı ile s27 “Ticari iş birliği yaptığımız tedarikçilerimiz ile bilgi paylaşımı ticari ilişkiyi tamamlayan bir bütündür." maddesi olduğu belirlenmiştir. Müşteri 
İlişkileri Yönetimi (MIY) boyutunda en etkili maddenin 0,825'lik katsayı ile s15 "Müşterilerimizin memnuniyeti sürekli gözlemler ve değerlendiririz.", Erteleme (E) boyutunda 0,958'lik katsayı ile s31 "Firmamız daha müşteri siparişi kesinleşmeden, üretimin en son aşaması montaj hattını tam olarak erteleme imkanı ve kabiliyetine sahiptir.", Tedarik Gelişimi (TG) boyutunda 0,911'lik katsayı ile s3 "Firmamız tarafından tedarikçilerimizin geliştirilmesi için ekipler oluşturulur.", Stratejik Tedarikçi Ortaklığ1 (STO) boyutunda ,684' lük katsayı ile s10 "Tedarikçilerimizin üretim kalitelerini artırmaları için yardımcı oluruz." maddeleri olduğu belirlenmiştir.

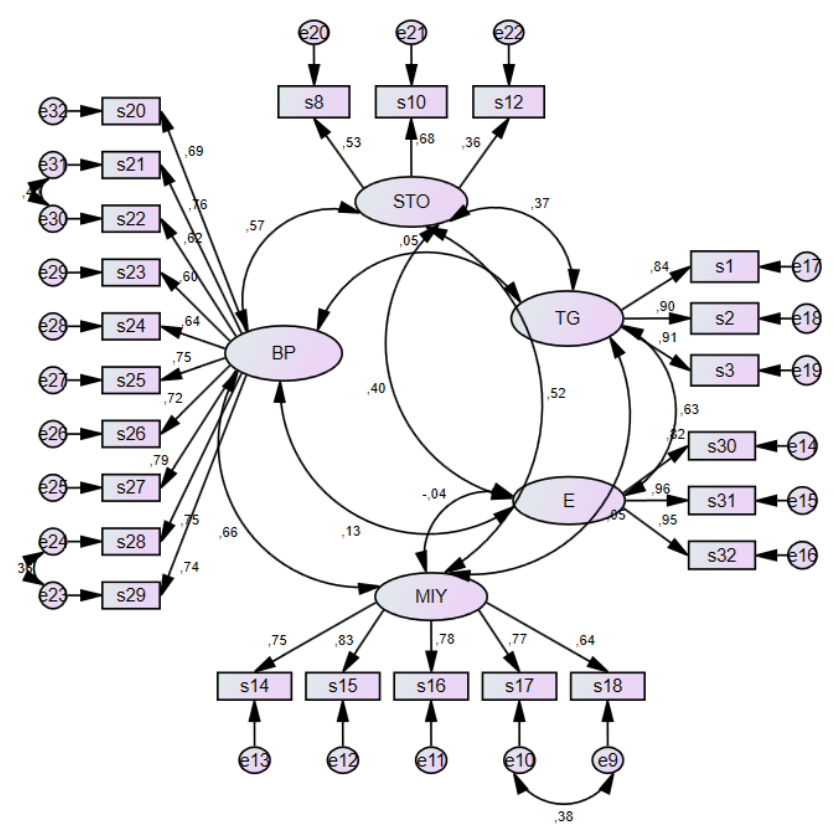

Şekil 2. Tedarik Zinciri Yönetimi Uygulamaları Ölçeği Doğrulayıcı Faktör Analizi

Bilgi paylaşımı alt boyutu ile Stratejik Tedarikçi Ortaklığı alt boyutu arasında 0.567, Müşteri İlişkileri ile 0.657 düzeyinde ilişki bulunmaktadır. Müşteri İlişkileri alt boyutu ile Stratejik Tedarikçi Ortaklığı arasında 0.525 düzeyinde ilişki bulunmaktadır. Stratejik Tedarikçi Ortaklığı alt boyutu ile Tedarikçi Gelişimi alt boyutları arasındaki ilişki 0.370, Erteleme ile 0,403 olarak belirlenmiştir. Erteleme alt boyutu ile Tedarikçi Gelişi alt boyutları arasında 0,632 düzeyinde ilişki bulunmaktadır.

İşletme Performansı ölçeğine madde analizi sonuçlarına bakıldığında, bir maddenin diğer maddelerle olan ilişkisinin 0,25 ' in altında olmaması gerektiğinden, işletme performansı ölçeğinden 8 nolu madde ölçekten çıkarılmıştır. Geriye 14 madde kalan ölçeğin nihai güvenirlik düzeyi sonuçları aşağıdaki tabloda verilmiştir.

Tablo 7. İşletme Performansı Ölçeğine İlişkin Güvenirlik Analizleri Sonuçları

\begin{tabular}{lrrrr}
\hline Maddeler & $\begin{array}{l}\text { Scale Mean if } \\
\text { Item Deleted }\end{array}$ & $\begin{array}{c}\text { Scale Variance } \\
\text { if Item Deleted }\end{array}$ & $\begin{array}{c}\text { Corrected Item- } \\
\text { Total Correlation }\end{array}$ & $\begin{array}{c}\text { Cronbach's Alpha } \\
\text { if Item Deleted }\end{array}$ \\
\hline ip1 & 45,09 & 61,615 &, 717 &, 897 \\
\hline
\end{tabular}




\begin{tabular}{lcccc}
\hline ip2 & 44,52 & 63,942 &, 552 &, 903 \\
\hline ip3 & 45,20 & 64,983 &, 264 &, 923 \\
\hline ip4 & 44,08 & 67,468 &, 306 &, 894 \\
\hline ip5 & 44,86 & 60,667 &, 792 &, 896 \\
\hline ip6 & 44,79 & 62,156 &, 758 &, 899 \\
\hline ip7 & 44,95 & 63,369 &, 655 &, 903 \\
\hline ip9 & 44,51 & 65,143 &, 546 &, 897 \\
\hline ip10 & 44,89 & 62,131 &, 714 \\
\hline ip11 & 44,82 & 60,797 &, 770 \\
\hline ip12 & 44,99 & 61,480 &, 789 &, 897 \\
\hline ip13 & 44,95 & 62,575 &, 712 &, 903 \\
\hline ip14 & 4451 &, 709 &, 897
\end{tabular}

Tablo 7 de bulunan işletme performansı ölçeğine ilişkin ölçeğinden 8 nolu madde ölçekten çıkarıldıktan sonraki madde analizi sonuçları incelendiğinde, ölçekten madde çıkarıma gerek olunmadığı sonucuna ulaşılmıştır. 14 maddelik ölçeğin genel güvenirlik düzeyleri incelendiğinde ölçeğin güvenirliğinin yüksek seviyede olduğu belirlenmiştir. (Cronbach's Alpha $=0,908$ )

Güvenilirlik analizi sonucu 8 nolu maddenin ölçekten çıkarılmasından sonra tüm soruların bulunduğu Açıklayıcı Faktör Analizi sonucunda tek faktörlü yapıda olan işletme performansı ölçeğinde faktör yükü 0,30 ' un üzerinde olmadığından dolayı ip3 “Ürün/hizmet üretip piyasaya verme süremiz rakiplerimizden hızlıdır" maddesi ölçekten çıkarılmıştır. Kalan 13 maddeyle yapılan açıklayıcı faktör analizine ait faktör yükleri, alt sınırın $(0,30)$ üzerinde olduğu tespit edildiğinden, iç tutarlılığın ve güvenilirliğin sağlandığ1 görülmüştür. Faktör yükleri 0.309 ile 0.859 arasında bulunmaktadır. Ayrıca KMO değerinin 0,911 olması ve Barlett's testinin sonucunun anlamlı olması, her boyut için toplanan verilerin araştırmada kullanılan ölçekle uyumlu bir şekilde faktörler altında toplanabileceğini ve araştırma konusu ile ilgili yazını desteklediği görülmektedir. Araştırma modeli toplam varyansın $\% 53,990^{\prime} ı n ı$ açıklamaktadır.

Tablo 8. İşletme Performansı Ölçeğine Ait DFA Sonuçları

\begin{tabular}{|c|c|c|c|c|c|}
\hline Ölçüm Adı & Mükemmel Uyum & Kabul Edilebilir Uyum & Modelin Ulaştığı sonuç & Modelin & Başarı \\
\hline & & & & Düzeyi & \\
\hline$\chi^{2 / \mathrm{df}}$ & $0<\mathrm{X}^{2} / \mathrm{sd}<3$ & $0<\mathrm{X} 2 / \mathrm{sd}<5$ & 2,284 & + & \\
\hline RMSEA & RMSEA $\leq .05$ & RMSEA $\leq .09$ & ,086 & + & \\
\hline NFI & $.95 \leq \mathrm{NFI}<1.0$ & $.80 \leq \mathrm{NFI}<1.0$ & ,915 & + & \\
\hline NNFI (TLI) & TLI $\geq .95$ & $\mathrm{TLI} \geq .80$ & ,931 & + & \\
\hline CFI & $\mathrm{CFI} \geq .95$ & $\mathrm{CFI} \geq .80$ & ,950 & + & \\
\hline
\end{tabular}


GFI

GFI $\geq .90$

GFI $\geq .80$

,905

Schermelleh ve Moosbrugger, (2003)

Tablo 8 incelendiğinde ölçeğe ait RMSEA kriteri ilk aşamada istenilen düzeyde çıkmadığından dolayı ip1-ip5, ip2-ip4, ip4-ip14, ip5-ip6, ip7-ip9, ip7-ip10, ip9-ip14, ip7-ip15 maddeleri arasında modifikasyon yapılmıştır. Uyum iyiliği değerlerini iyileştirmek maksadıyla gerçekleştirilecek modifikasyonlar; oluşturulması gereken yeni bağlantıları, modelden çıkarılması gereken değişkenleri ve değişkenler arasında eklenmesi uygun görülen hata kovaryanslarını içermektedir (Bayram, 2016: 57). Yapılan modifikasyonlar uygun uyum indeksleri elde edilirse ölçek kabul edilecektir. Aksi durumda yapılabiliyorsa tekrar düzeltme yoluna gidilir ve bu işleme yeni bir modifikasyon yapılamayana kadar devam edilir (Meydan ve Şeşen, 2015: 41). Uygulanan DFA ile maddelerin ilgili faktörleri \%95 güven düzeyinde doğrulandığ1 $(p<0.05 \mathrm{p}=0,000)$ ve $\mathrm{X} 2 / \mathrm{sd}^{\prime}$ nin ve diğer uyum kriterlerinin mükemmel uyum aralıklarında olduğu belirlenmiştir.

\subsection{Regresyon Analizi}

Tablo 10'daki verilere göre her bir ikili ilişki için " $\mathrm{p}$ " değerleri 0,05 'ten küçük olması, faktör yüklenimleri açısından önemlidir. Faktör yüklenimlerinin önemli çıkması maddelerin, faktörlere doğru yüklendiği anlamına gelmektedir (Karagöz, 2017: 481-482). Bunun sonucunda işletme performansı ölçeğinin doğrulayıcı faktör analizi yapısı aşağıdaki şekilde açıkça görülmektedir.

Tablo 9. İşletme performansı Ölçeğine Ait Regresyon Katsayıları Tablosu

\begin{tabular}{lllllll}
\hline & & & Estimate & S.E. & C.R. & P \\
\hline ip15 & $<---$ & IP &, 753 & & & \\
ip14 & $<---$ & IP &, 488 &, 104 & 6,466 & $* * *$ \\
ip13 & $<--$ & IP &, 825 &, 087 & 11,468 & $* * * *$ \\
ip12 & $<---$ & IP &, 851 &, 088 & 11,892 & $* * *$ \\
ip11 & $<---$ & IP &, 825 &, 096 & 11,476 & $* * *$ \\
ip10 & $<---$ & IP &, 810 &, 092 & 11,156 & $* * *$ \\
ip9 & $<--$ & IP &, 550 &, 086 & 7,271 & $* * *$ \\
ip7 & $<---$ & IP &, 797 &, 102 & 9,386 & $* * *$ \\
ip6 & $<---$ & IP &, 799 &, 086 & 11,056 & $* * *$ \\
ip5 & $<--$ & IP &, 799 &, 095 & 11,050 & $* * *$ \\
ip4 & $<--$ & IP &, 209 &, 095 & 2,722 &, 006 \\
ip2 & $<---$ & IP &, 482 &, 098 & 6,387 & $* * *$ \\
ip1 & $<--$ & IP &, 722 &, 097 & 9,860 & $* * *$ \\
\hline
\end{tabular}




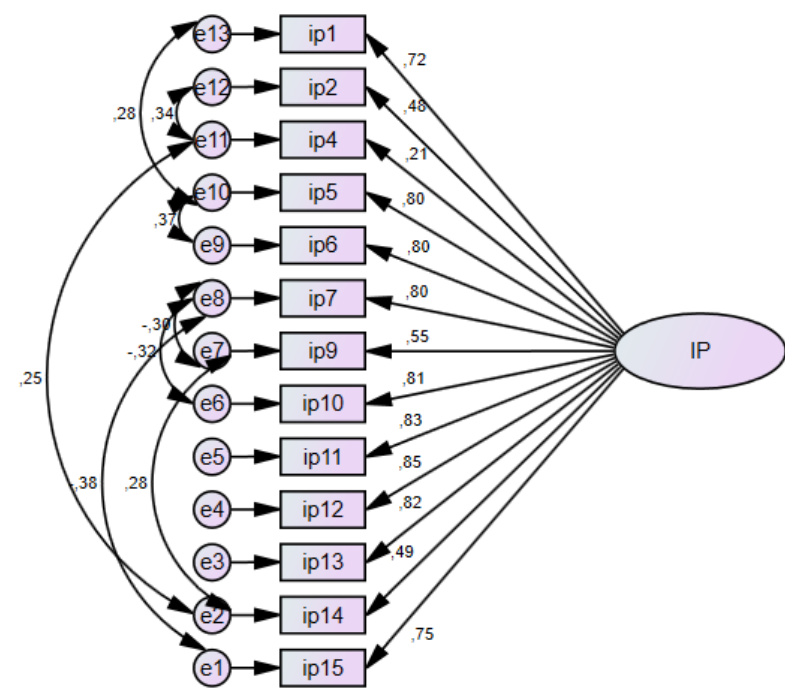

Şekil 3. İşletme Performansı Ölçeği Doğrulayıcı Faktör Analizi

İşletme performansında en etkili değişkenin 0,851' lik katsayı ile ip12 “Faaliyet gelirlerimiz rakiplerimizden yüksektir" maddesi olduğu belirlenmiştir.

\subsection{Korelasyon Analizi}

Araştırmada uygulanan ölçekler arasındaki ilişki düzeyini incelemek için korelasyon analizi uygulanmıştır. Korelasyon analizine göre işletme performansı ile tedarik zinciri yönetimi uygulamaları alt boyutlarından bilgi paylaşımı, tedarikçi gelişimi arasında pozitif yönlü düşük kuvvetli bir ilişki bulunmaktadır.

Tablo 10. Ölçeklerin Arasındaki Korelasyon Katsayıları

\begin{tabular}{|c|c|c|c|c|c|c|c|c|}
\hline Değişkenler & & BP & TG & STO & MIY & E & $\mathrm{TZY}$ & İP \\
\hline \multirow{2}{*}{$\mathrm{BP}$} & $\mathrm{r}$ & 1 & ,050 & $387^{* *}$ &, $552^{* *}$ & 131 &, $741^{* *}$ & ,229** \\
\hline & $\mathrm{p}$ & & ,510 & ,000 & 000 & ,083 & ,000 & ,002 \\
\hline \multirow{2}{*}{ TG } & $\mathrm{r}$ & & 1 &, $319^{* *}$ & ,061 & $611^{* *}$ & $611^{* *}$ & ,209* \\
\hline & $\mathrm{p}$ & & & , 000 & ,418 & ,000 & ,000 & ,005 \\
\hline \multirow{2}{*}{ STO } & $\mathrm{r}$ & & & 1 & $315^{* *}$ & $347^{* *}$ & $648^{* *}$ & ,146 \\
\hline & $\mathrm{p}$ & & & & ,000 & ,000 & ,000 & ,053 \\
\hline \multirow{2}{*}{ MIY } & $\mathrm{r}$ & & & & 1 &,- 034 &, $575^{* *}$ & 100 \\
\hline & $\mathrm{p}$ & & & & & 649 & ,000 & , 185 \\
\hline \multirow{2}{*}{$\mathrm{E}$} & $\mathrm{r}$ & & & & & 1 & $619^{* *}$ & , 054 \\
\hline & $\mathrm{p}$ & & & & & & ,000 & 476 \\
\hline \multirow{2}{*}{$\mathrm{TZY}$} & $\mathrm{r}$ & & & & & & 1 & $246^{* *}$ \\
\hline & $\mathrm{p}$ & & & & & & & ,001 \\
\hline \multirow[t]{2}{*}{$\dot{\mathrm{IP}}$} & $\mathrm{r}$ & & & & & & & 1 \\
\hline & $\mathrm{p}$ & & & & & & & \\
\hline
\end{tabular}

BP: Bilgi Paylaşımı, TG: Tedarikçi Gelişimi, STO: Stratejik Tedarikçi Ortaklığı, MIYY: Müşteri 
İlişkileri Yönetimi, E: Erteleme, İP: İşletme Performansı

\subsection{Yapısal Eşitlik Modellemesi}

Araştırma kapsamında oluşturulan hipotezler IBM AMOS 24 Programı ile test edilmiştir. Veriler normal dağılım gösterdiğinden Maximum Likelihood hesaplama metodu ile kovaryans matrisi oluşturulmuştur. Çalışmanın amacına ve modeline uygun olan, örtük değişkenler ile değişkenler arasındaki dolaylı etkilerin test edildiği YEM modeli (yapısal eşitlik modeli) kullanılmıştır (Gürbüz, 2019: 106).

Tablo 11. Yapısal Model İçin Uyum Değerleri

\begin{tabular}{|c|c|c|c|c|c|}
\hline Ölçüm Adı & Mükemmel Uyum & Kabul Edilebilir Uyum & Modelin Ulaştı̆ı̆ sonuç & $\begin{array}{l}\text { Modelin } \\
\text { Düzeyi }\end{array}$ & Başarı \\
\hline$\chi^{2 / d f}$ & $0<\mathrm{X}^{2} / \mathrm{sd}<3$ & $0<\mathrm{X} 2 / \mathrm{sd}<5$ & 2,309 & + & \\
\hline RMSEA & RMSEA $\leq .05$ & RMSEA $\leq .09$ & 0,087 & + & \\
\hline NFI & $.95 \leq \mathrm{NFI}<1.0$ & $.80 \leq \mathrm{NFI}<1.0$ & 0,718 & + & \\
\hline NNFI (TLI) & $\mathrm{TLI} \geq .95$ & $\mathrm{TLI} \geq .80$ & 818 & + & \\
\hline IFI & $.95 \leq \mathrm{NFI}<1.0$ & $.90 \leq \mathrm{NFI}<1.0$ & 800 & + & \\
\hline CFI & $\mathrm{CFI} \geq .95$ & $\mathrm{CFI} \geq .80$ & ,816 & + & \\
\hline
\end{tabular}

Schermelleh ve Moosbrugger, (2003)

Model uyum iyiliği değerleri incelendiğinde özellikle CMIN/df (2.30), CFI (0.86), RMSEA $(0.08)$ ve TLI $(0,18)$ başta olmak üzere neredeyse tüm uyum iyiliği değerlerinin kabul edilen eşik değerlerin içerisinde olduğu gözlemlenmektedir. Fakat elde edilen NFI VE IFI değerlerinin iyi uyuma sahip olmadığı görülmektedir. Buna rağmen, elde edilen diğer indekslerin iyi uyum değerlerine sahip olması modelin veri ile uyumlu olduğunu söylemek için yeterlidir. Nitekim, NFI ve IFI değerlerinin eşik değerlerin altında veya eşik değerlere oldukça yakın olması Şimşek (2007)'e göre örneklem büyüklüğünden kaynaklanmakta ve modelin uyum iyiliğini bozmamaktadır (Dağlı, 2015: 212). Araştırmada oluşturulan yapısal modelin test edildiği standardize yol diyagramı Şekil 3'te verilmiştir. 


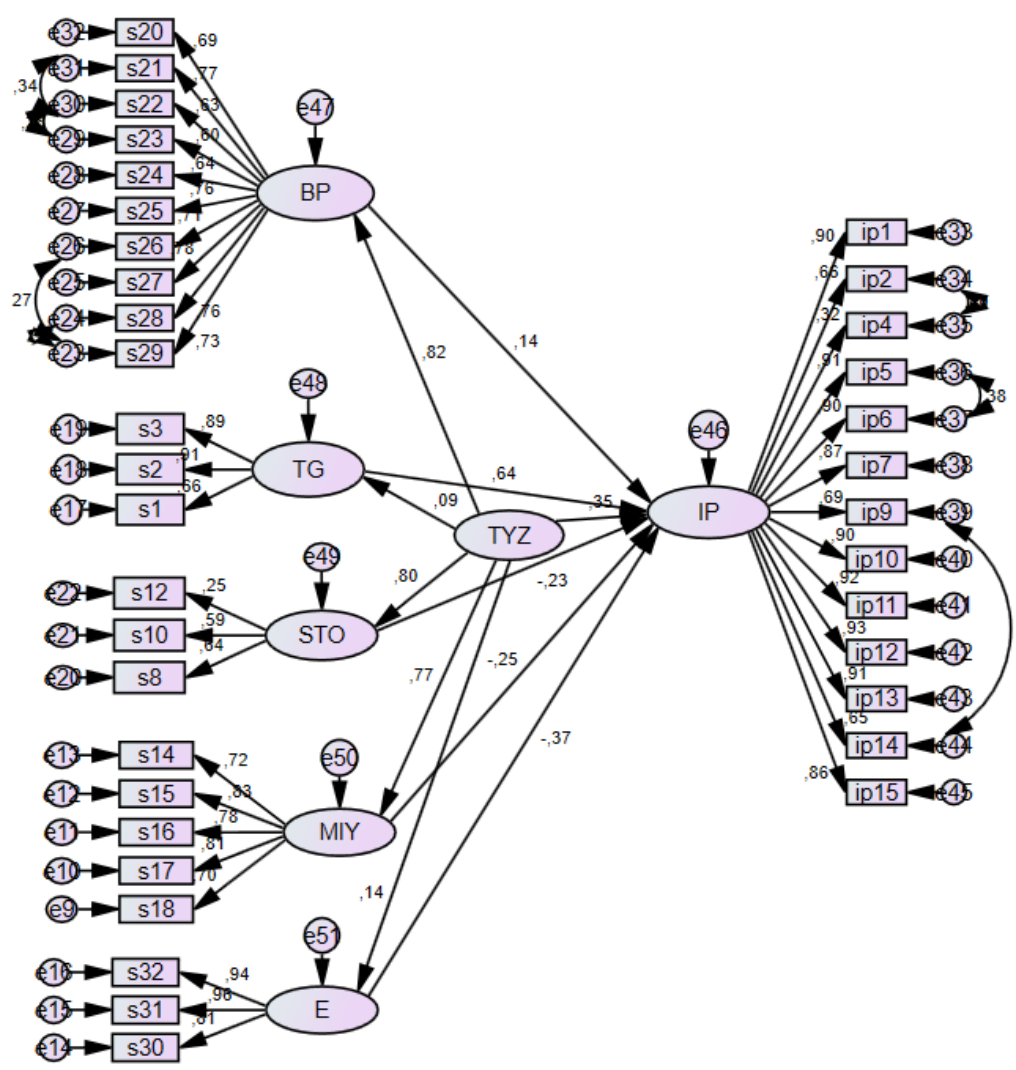

Şekil 4. Standardize Yol Diyagramı

Ölçme modellerinin doğrulandıktan sonra, örtük değişkenli yapısal eşitlik modellemesi ile araştırma hipotezleri test edilmiştir. Analiz sonuçları Şekil 4 ve Tablo 13'te sunulmuştur.

Tablo 12. Araştırma Modeline İlişkin Yapısal Model Standardize Yol Katsayıları ve Analiz Sonuçları

\begin{tabular}{lccccccc}
\hline Test Edilen Yol (Hipotezler) & & & $\beta$ & S. $\beta$ & T (CR) & p & Sonuç \\
\hline TYZ & $\rightarrow$ & IP & 1,000 &, 349 & & - & Kabul \\
TYZ-Bilgi Paylaşımı & $\rightarrow$ & IP &, 336 &, 144 & 1,301 &, 193 & Red \\
TYZ-Tedarikçi Gelişimi & $\rightarrow$ & IP & 1,000 &, 643 & & - & Kabul \\
TYZ-Stratejik Tedarikçi Ortaklığı & $\rightarrow$ & IP &,- 570 &,- 227 & $-1,609$ &, 108 & Red \\
TYZ-Müşteri Illişkileri Yönetimi & $\rightarrow$ & IP &,- 650 &,- 248 & $-2,511$ &, 012 & Kabul \\
TYZ-Erteleme & $\rightarrow$ & IP &,- 409 &,- 367 & $-6,133$ & $* * *$ & Kabul \\
\hline
\end{tabular}

Tablo 12'deki verilere göre, bilgi paylaşımı $\rightarrow$ işletme performansı ve stratejik tedarikçi ortaklığ $1 \rightarrow$ işletme performansı yolları dişındaki diğer yolların " $p$ " değerlerinin 0,05 'den küçük olması ile faktör yüklenimleri ve gizil değişkenler arasındaki ilişkilerin önemli olduğu görülmüştür. $\mathrm{H}_{2}$ ve $\mathrm{H}_{4}$ hipotezleri reddedilmiştir. Şekil 4, Tablo 11-12'deki verilerden yararlanılarak aşağıdaki yorumlar yapılmaktadır:

Öncelikle $\mathrm{H}_{1}$ (Tedarik Zinciri Yönetimi Uygulamaları $\rightarrow$ İşletme Performansı) hipotezini test etmek amacıyla Tedarik Zinciri Yönetimi algı düzeyinin dışsal işletme performansı ise içsel 
değişken olduğu örtük değişkenli yapısal model test edilmiştir. YEM sonuçlarına göre Tedarik Zinciri Yönetimi alg1 düzeyinin işletme performansını yordadığ1 $(ß=.349 ; \mathrm{p}<.01)$ tespit edilmiş; bu durumda $\mathrm{H}_{1}$ hipotezi kabul edilmiştir.

Araştırma modeli kapsamında yapılan yol analizi sonuçlarına göre tedarik zinciri yönetimi alt boyutlarından müşteri ilişkileri yönetimi, erteleme boyutları işletme performansı üzerinde negatif yönde anlamlı bir etkisi bulunmaktadır. Tedarikçi gelişimi alt boyutu işletme performansını olumlu yönde etkilemektedir. Bu bağlamda $\mathrm{H}_{3}, \mathrm{H}_{5}, \mathrm{H}_{6}$ hipotezleri kabul edilmiştir.

\section{SONUÇ VE ÖNERILER}

Günümüzde yoğun olarak yaşanan rekabet ortamında, işletmelerin performansları sadece kendi yeteneklerinden kaynaklanmamaktadır. Bunu belirleyen birden çok faktör bulunmaktadır. Son yıllarda işletmelerin dış kaynaktan yararlanma oranları, tedarik amaçlı küçülme ve ortaklıklar gibi yönelimler işletmelerin tedarikçilere olan güvenini artırmaktadır (Sağbaş, 2015: 58).

Global piyasalarda yeni ürün üretme yönünde devam etmekte olan rekabet ortamı, tüketicileri kaliteli, ancak fiyatı düşük ürünlere yönlendirmiştir. Buradan hareketle, dünya çapındaki firmaların uzun dönemli ve sürdürülebilir performanslı olabilmeleri onların ürün ve süreç yeniliklerindeki performanslarına bağlıdır. Yapılan araştırmalar gösteriyor ki, ürün ve süreç yeniliği küresel piyasalarda yüksek kazançlı rekabet avantajlarının kaynağıdır. Tedarik zincirinde ürün ve yenilik faaliyetlerine dâhil edilen tedarikçiler zaman, maliyet ve tasarım süresi gibi konulardaki faydalarıyla işletmelerin performansının daha yukarı çıkmasını sağlamışlardır (Şen, 2010: 135-136).

Literatürde, tedarikçilerin teslim yeteneğinin işletmelere rekabet avantajı sağladığı görülmektedir. Hız ve güvenilirlik, teslim yeteneğinin iki önemli alt boyutudur. Tedarikçiler teslim yeteneklerini gösterebilmek için alıcıya kesin teslimat tarihi vermeliler ve bu tarihte ürünü teslim etmelidirler. Böylece tedarikçiler, işletmelerin üretim akışını kesmeden üretmelerini sağlayarak performanslarını pozitif yönde etkilerler (Bedük, 2009: 97).

$\mathrm{Bu}$ çalışmada, Gaziantep il merkezinde bulunan üretim işletmelerinden toplanan verilerin analiz bulguları yer almaktadır. Gaziantep il merkezinde bulunan üretim işletmelerinde tedarik zinciri yönetimi uygulamalarının işletme performansına etkisi incelenmiştir. Tedarik zinciri yönetimi uygulamalarını oluşturan ifadeler beş boyutta incelenmiştir.

Birinci boyut olan bilgi paylaşımı boyutunda en etkili değişkenin 0,792'lik katsayı ile “Ticari iş birliği yaptığımız tedarikçilerimiz ile bilgi paylaşımı ticari ilişkiyi tamamlayan bir bütündür." maddesi olduğu belirlenmiştir. Paylaşılan bilginin kalitesi ve seviyesinin yüksek olması TZ' nin performansının yükselmesine, maliyetlerin azalmasına ve müşteri hizmet kalitesini artırarak işletmelere pozitif katkılar sunmaktadır (Urk, 2016: 81). İşletmeler ticari hayatlarını devam ettirebilmek için diğer işletmelerle iş birliği yapmak durumundalar. Yapılan iş birliklerinden daha fazla faydalanmak için işletmeler birbirleriyle sürekli bir bilgi alış-verişi içerisinde olmalıdırlar. Bu şekilde iş birliklerinden en üst seviyede faydalanabilirler. Literatürde de bu sonucu destekler çalışmalar bulunmaktadır (Şahin, 2018; Yön, 2007; Urk, 2016). 
İkinci boyut olan Müşteri İlişkileri Yönetimi (MİY) boyutunda en etkili maddenin 0,825' lik katsayı ile "Müşterilerimizin memnuniyeti sürekli gözlemler ve değerlendiririz." maddesi olduğu belirlenmiştir. İşletmelerin devamlılık sağlayabilmeleri için en önemli değerleri olan müşterilerini sürekli memnun etmeleri gerekmektedir. Bunun için ise müşterileriyle sürekli irtibatta kalmaları gerekmektedir. Bir üründen kaynaklanan müşteri mağduriyetini çözmeli ve müşteriyi memnun bir şekilde göndermelidir. Yapılan analiz sonucunda da görülüyor ki tedarik zinciri yönetiminde müşteri memnuniyeti sürekli gözlemlenmektedir. Literatürde de bu sonucu destekler çalışmalar bulunmaktadır (Civelek,2016; Yıldız, 2010; Yayla ve Ungan, 2019; Yağc1, 2009; Güçlü, 2010).

Üçüncü boyut olan erteleme boyutunda en etkili değişken 0,958'lik katsayı ile "Firmamız daha müşteri siparişi kesinleşmeden, üretimin en son aşaması montaj hattını tam olarak erteleme imkânı ve kabiliyetine sahiptir." maddesi olduğu belirlenmiştir. Erteleme işletmeler için önemlidir. Çünkü işletmeler müşteriden sipariş gelene kadar üretimi ertelerler bu şekilde hem müşterinin istekleri doğrultusunda ürün üreterek müşteriyi memnun ederler hem de işletmeler ürün üreterek katlanacakları depolama masrafından kurtulurlar. Böylece işletmenin maliyetleri artmamış olur. (Urk, 2016; Yön, 2007; Öztürk ve Tekin, 2020)

Dördüncü boyut olan tedarikçi gelişimi boyutunda en etkili değişken 0,911'lik katsayı ile "Firmamız tarafından tedarikçilerimizin geliştirilmesi için ekipler oluşturulur." maddesi olduğu belirlenmiştir. Anket uygulanan işletmelerin büyük çoğunluğunda tedarikçileri geliştirmek için herhangi bir ekip ile tedarikçi ziyaretleri yapılmamaktadır.

Beşinci boyut olan stratejik tedarikçi ortaklığı boyutunda en etkili değişken 0,684' lük katsayı ile "Tedarikçilerimizin üretim kalitelerini artırmaları için yardımcı oluruz." maddesi olduğu belirlenmiştir. Stratejik tedarikçi ortaklığı işletmeler için kaynak, güç ve sürdürülebilirlik sağlamaktadır. İşletmeler yapacakları bir işte zor olan kısmı ya da ekipmanı olmayan bölümü diğer işletmelerle stratejik ortaklık kurarak daha az maliyetle tamamlar. Kurulan bu ittifaklar işletmelere eksikliklerini tamamlama, öğrenen bir işletme olma ve kaynak kullanımı bakımından katkılar sağlamaktadır (Yayla ve Ungan, 2019; Yön, 2007; Demir ve Oktay, 2010).

İşletme performansı tek boyut olarak incelenmiştir. İşletme performansında en etkili değişkenin 0,851'lik katsayı ile "Faaliyet gelirlerimiz rakiplerimizden yüksektir" maddesi olduğu belirlenmiştir. Müşterilerin de bu işletmeden memnun olduğunu ve işlemlerini bu işletme ile yapmaya devam ettiği ve bu şekilde işletmenin genel performansın arttığ1 görülmektedir (Civelek, 2016; Yıldız, 2010; Yayla ve Ungan, 2019; Erdem 2013; Güçlü, 2010).

Yapılan çalışmada tedarik zinciri yönetimi uygulamalarının işletme performansına pozitif yönde etkisinin olduğu tespit edilmiştir. İşletmeler karlarını artırmak için ya ürünlerini yüksek fiyata satacaklar ya da maliyetlerini minimum seviyesinde tutacaklar. İşletmeler yoğun rekabet ortamında ürünlerini yüksek fiyatlara satamazlar bundan dolayı maliyetlerini minimum seviyesinde tutmalıdırlar. Bunu ise hammadde tedarik ettikleri zincirlerle daha iyi ilişkiler kurarak sağlayabilirler. Üretim işletmelerinin üretmiş oldukları ürünleri müşterilerine en az maliyetle ulaştırabilmeleri için de yine bir tedarik zincirine ihtiyaçları vardır. Sonuçta, tedarik zinciri yönetimi uygulamalarının işletmelerin hem hammadde tedarikinde hem de ürünlerinin müşterilerine ulaştırılması noktasında en önemli faaliyetlerden birisi olarak karşımıza çıkmaktadır. Bundan dolayı işletmeler kar oranlarını 
artırmak ve ileriye dönük daha iyi iş yapabilmek için tedarik zinciri yönetimine önem vermelidirler.

Çalışma daha sonra yapılacak olan çalışmalarda tedarik zinciri yönetimi uygulamaları alt boyutlarıyla birlikte, işletme performansı rekabet gücü gibi konularda farklı sektörlerde ve farklı il veya bölgelerde uygulanabilir. Tedarik zinciri yönetiminin alt boyutlarını ayrı ayrı işletme performansına etkisine farklı sektörlerde farklı il veya bölgelerde bakılabilir. Böylece farklı yerlerde yapılan uygulamalar ile işletmelere katkı sağlanmış olunur.

\section{KAYNAKÇA}

Acar, M. (2003). Tarımsal İşletmelerde Finansal Performans Analizi. Erciyes Üniversitesi İktisadi ve İdari Bilimler Fakültesi Dergisi, (20). 21-37.

Acar, Ö. E., ve Köylüoğlu, A. S. (2020). Sürdürülebilir Tedarikçi Seçiminin Analitik Hiyerarşi Prosesi (AHP) Yöntemiyle Analizi. Third Sector Social Economic Review, 55(1), 419-440. doi: 10.15659/3.sektor-sosyal-ekonomi.20.03.1286

Aydıntan, B. (2003). Dışa Açılma Yolunda Stratejik Ortaklıklar ve Türk Şirketleri Açısından Önemi. Gazi Üniversitesi İktisadi ve İdari Bilimler Fakültesi Dergisi, 5(2), 135-152.

Bayram, N. (2016). Yapısal Eşitlik Modellemesine Giriş: AMOS Uygulamaları. (3.Baskı). Bursa: Ezgi Kitabevi.

Bedük, M. (2009). Tedarik Zinciri Yönetiminin Isşletme Performansı Üzerindeki Etkisi: Örnek Olay Çalışması. Yayınlanmamış yüksek lisans tezi, Selçuk Üniversitesi, Konya.

Civaroğlu, G. (2006). Tedarik Zinciri Yönetimi Uygulamaları Ve Performans Üzerine Etkilerinin Analizi. Yayınlanmamış yüksek lisans tez, Trakya Üniversitesi, Edirne.

Civelek, A. (2016). Konaklama İşletmelerinde Müşteri İlişkileri Yönetiminin İşletme Performansına Etkisi: 5 Yıldızlı Oteller Üzerine Bir Uygulama. Selçuk Üniversitesi Sosyal Bilimler Meslek Yüksek Okulu Dergisi, 19(2), 233-253.

Çemberci, M., Sözer, E., \& Civelek, M. E. (2015). Firmalar Arası Bilgi Paylaşımı ile Tedarik Zinciri Yönetimi Performansı İlişkisinde Bilgi Kalitesinin Moderatör Etkisi (The Moderating Role of Information Quality on the Relation between Inter-Company Information Share and Supply Chain Management Performance). Yönetim Bilimleri Dergisi, 13(25), 141-159.

Dağlı, A. (2015). Örgütsel Muhalefet Ölçeğinin Türkçe'ye Uyarlanması: Geçerlilik ve Güvenirlik Çalışması. Elektronik Sosyal Bilimler Dergisi, 14 (53). 198-218.

Demir, C. ve Oktay, S. (2010). Stratejik İttifak Oluşumunda Temel Yeteneklerin Önemi. Ege Stratejik Araştırmalar Dergisi, 1(1), 45-58.

Demirel, Y. (2007). Bilgi ve Bilgi Paylaşımının İşletme Performansına Etkisi Üzerine Bir Araştırma. Yönetim Bilimleri Dergisi, 5(2), 91-106.

Demirtaş, Ö., ve Akdoğan, A. (2014). Bulanık Ortamda Tedarikçi Seçimi: Savunma Sanayii'ne Yönelik Bir Uygulama. Erciyes Üniversitesi İktisadi ve İdari Bilimler Fakültesi Dergisi, (43), 203-222. 
Erdem, G. (2013). Tedarik Zinciri Yönetimi Uygulamalarının Benimsenmesinin, Tedarik Zinciri ve İşletme Performansına Etkisi. Yayınlanmamış yüksek lisans, Hitit Üniversitesi, Çorum.

Ferreira, K. A., Toledo, M. L., and Rodrigues, L. F. (2020). Postponement practices in the Brazilian Southeast wine sector. The International Journal of Logistics Management.

Ferreira, K. A., Tomas, R. N., and Alcântara, R. L. C. (2015). A Theoretical Framework For Postponement Concept in A Supply Chain. International Journal of Logistics Research and Applications, 18(1), 46-61.

Gilanlı, E., Çetin, O., ve Altuğ, N. (2019). Tedarik Zincirinde Bilgi Paylaşımı ve Lojistik Entegrasyonun Pazara Giriş Hızı Üzerindeki Etkisi. Sosyal Bilimler Araştırma Dergisi, 8(1), 54-60.

Günal, S. (2010). Tedarikçi Seçim Stratejileri ve Bir Uygulama. Yayınlanmamış yüksek lisans tezi, Uludağ Üniversitesi, Bolu.

Gürbüz, S. ve Şahin, F. (2016). Sosyal Bilimlerde Araştırma Yöntemleri. (3.Baskı). Ankara: Seçkin Yayıncılık.

Gürbüz, S. (2019). AMOS ile Yapısal Eşitlik Modellemesi, Ankara: Seçkin Yayıncılık.

Kalaycı, Ş. (2008). SPSS Uygulamalı Çok Değişkenli İstatistik Teknikleri, 3. Baskı, Ankara: Asil Yaymevi.

Karagöz, Y., (2017). SPSS ve AMOS Uygulamalı Nitel-Nicel Karma Bilimsel Araştırma Yöntemleri ve Yayın Etiği, Nobel yayıncılık.

Koçoğlu, İ. (2010). Tedarik Zinciri Yönetiminde Yenilik ve Bilgi Paylaşımının Önemi. Yayınlanmamış yüksek lisans tezi, Gebze Yüksek Teknoloji Enstitüsü, Gebze.

Korkmaz, Ö. (2010). Müşteri İlişkileri Yönetiminin (Crm) Önemi: Bir Hastane Uygulaması. Yayınlanmamış yüksek lisans, Dokuz Eylül Üniversitesi, İzmir.

Medrano, L.A., Liporace, M.F. and Prez, E. (2014). Computerized Assessment System For Academic Satisfaction (ASAS) For First-Year University Student, Electronic Journal of Research in Educational Psychology, 12 (2). 541-562.

Meydan, C. H. ve Şeşen, H. (2015), Yapısal Eşitlik Modellemesi: AMOS Uygulamaları, 2.Baskı, Ankara: Detay Yayıncılık.

Özgüner, M. (2019). Tedarik Zinciri Risklerinin Lojistik Performans Üzerindeki Etkisinin Yapısal Eşitlik Modellemesi ile Belirlenmesi. Eskişehir Osmangazi Üniversitesi İ̈BF Dergisi, 14(1), 67-82.

Özgüner, Z. (2017). Lojistik Faaliyetlerin Süreçsel Etkinliğinde Rol Oynayan Değişkenlerin İşletme Performansına Etkisinde Lojistik Performansın Aracılık (Medıator) Rolü. Yayınlanmamış doktora tezi, Hasan Kalyoncu Üniversitesi, Gaziantep.

Özilhan, D. (2010). Müşteri İlişkileri Yönetimi (MIY) Uygulamalarının İşletme Performansına Etkileri. Gümüşhane Üniversitesi Sosyal Bilimler Elektronik Dergisi,sayı (1) 18-30 
Öztürk, D. ve Tekin, M. (2020). Tedarik Zinciri Yönetiminin İşletme Performansı Üzerindeki Etkisi: Gida Sektöründe Bir Uygulama. Research Journal of Business and Management, 7(2), 56-66.

Paksoy, T., ve Keskin, E. (2006). Tedarik Zincirinde Bilgi Çarpıtmasının Etkisi: Kırbaç Etkisi. Selçuk Üniversitesi Sosyal Bilimler Enstitüsü Dergisi, (15), 483-496.

Rahımı, R. (2013). Örgüt Kültürü Perspektifi ile Otelcilik Sektöründe Müşteri İlişkileri Yönetimi: Jurys Inn Zincir Otelleri Örneği. Yayınlanmamış doktora tezi, Dokuz Eylül Üniversitesi, İzmir.

Sağbaş, M. (2015). Tedarik Zinciri Yönetiminde Bilgi Teknolojileri, Çeviklik Ve Entegrasyonun Operasyonel Ve Finansal Performansa Etkisi. Yayınlanmamış Doktora Tezi, Beykent Üniversitesi, İstanbul.

Schermelleh-Engel, K. Ve Moosbrugger, H. (2003), Evaluating The Fit of Structrual Equation Models: Test of Signicance and Descriptive Goodness-of-Fit Measures, Methods of Psychological Research Online, Vol:8, No:2, 23-74.

Şahin, H. (2018). Tedarik Zincirinde Bilgi Paylaşımının İşletme Performansına Etkileri. Yayınlanmamış Doktora Tezi, Sakarya Üniversitesi, Sakarya.

Şahin, M. (2019). Tedarik Zincirinde Risk Yönetiminin İşletme Performansına Etkisi: İstanbul İlinde Bir Araştırma. Yayınlanmamış yüksek lisans, İstanbul Üniversitesi, İstanbul.

Şen, M. (2010). Tedarik Zinciri Yönetiminin Kobilerde Isşletme Performansı Üzerine Etkileri Ve Bir Örnek Uygulama. Yayınlanmamış yüksek lisans, Selçuk Üniversitesi, Konya.

Toptancı, A.R. (2013). Tedarik Zinciri Yönetimi Uygulamalarının Üretim Performansına Etkileri Konusundaki Yönetici Algılamaları: Kahramanmaraş Gaziantep ve Diyarbakır Illerinde Faaliyet Gösteren Imalat İşletmelerinde Ampirik Bir Araştırma. Yayınlanmamış yüksek lisans, Kahramanmaraş Sütçü İmam Üniversitesi, Kahramanmaraş.

Ungan, M.C. (2011). En İyi Tedarik Zinciri Uygulamaları ve Bir Saha Çalışması. Süleyman Demirel Üniversitesi İktisadi ve İdari Bilimler Fakültesi Dergisi, C.16, S.2, s.307-322.

Urk, H. (2016). Tedarik Zinciri Yönetimi Uygulamalarının Tedarik Zinciri ve Şirket Performansı Üzerine Etkilerinin Ampirik Analizi. Yayınlanmamış doktora tezi, Haliç Üniversitesi, İstanbul.

Yağcı, K. (2009). Tedarik Zinciri Yönetimi Uygulamalarının Konaklama İşletmeleri Performansına Etkileri. Yayınlanmamış doktora tezi, Dokuz Eylül Üniversitesi, İzmir.

Yıldız, D. (2010) Müşteri ilişkileri yönetimi (CRM) uygulamalarının işletme performansına etkileri ve bir uygulama Yayınlanmamış yüksek lisans tezi, Dumlupınar Üniversitesi, Kütahya.

Yön, I. (2007). Tedarik Zinciri Yönetimi Uygulamalarının Rekabet Gücüne Etkisi. Yayınlanmamış yüksek lisans tezi, Gaziantep Üniversitesi, Gaziantep. 